\title{
INVOLVING PRIVATE SECTOR DEVELOPERS: BUILDING AFFORDABLE RENTAL HOUSING IN THE CITY OF TORONTO
}

By Andrew Cohrs

BA Joint Anthropology \& Geography, University of Northern British Columbia, Class of 2009

An MRP presented to Ryerson University in partial fulfillment of the requirements for the degree of Masters of Planning in Urban Development (MPL)

Toronto, Ontario, Canada, 2014

(C)Andrew Cohrs 2014 


\section{AUTHOR'S DECLARATION}

I hereby declare that I am the sole author of this MRP. This is a true copy of the MRP, including any required final revisions.

I authorize Ryerson University to lend this MRP to other institutions or individuals for the purpose of scholarly research.

I further authorize Ryerson University to reproduce this MRP by photocopying or by other means, in total or in part, at the request of other institutions or individuals for the purpose of scholarly research.

I understand that my MRP may be made electronically available to the public. 


\section{ABSTRACT}

INVOLVING PRIVATE SECTOR DEVELOPERS: BUILDING AFFORDABLE RENTAL HOUSING IN THE CITY OF TORONTO

Andrew Cohrs (Masters of Planning in Urban Development, Ryerson University, 2014)

This research makes the argument for increasing private sector participation in affordable housing development in the City of Toronto. It explores the demand for affordable rental housing in Toronto, examines the national, provincial and municipal legislative situation affecting Toronto and demonstrates the potential for the municipality of Toronto to update and implement policies to produce more affordable housing with private sector developers. Policies used across Canada and the United States to encourage or require affordable housing contributions from private sector developers are explored and case studies of Vancouver, Montreal and San Francisco highlight how municipalities facing similar housing pressures have attempted to address their situations. Interviews with key stakeholders contributed Toronto-specific ideas regarding private sector involvement in the construction of affordable rental housing as well as the accompanying policies that have potential in Toronto. Actions and policies are recommended for the consideration of the Toronto municipal government.

\section{KEY THEMES}

affordable housing / affordable rental housing / residential development / housing policy / development process / private sector participation / financial tools / inclusionary zoning / public-private partnerships 


\section{ACKNOWLEDGEMENTS:}

I would like to thank Dr. Steven Webber, who provided invaluable assistance as primary Supervisor to this research. As well, Dr. Joseph Springer provided crucial support as Second Reader. As well, I would like to acknowledge the contributions of developers, public and not-for profit representatives who graciously shared their opinions and information. 


\section{TABLE OF CONTENTS}

INTRODUCTION ............................................................................................................................. 1

THE CASE FOR PRIVATE SECTOR PARTICIPATION IN AFFORDABLE RENTAL HOUSING...... 4

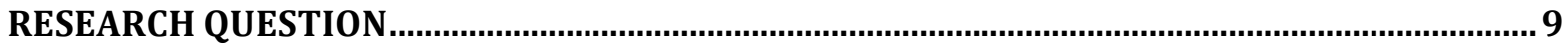

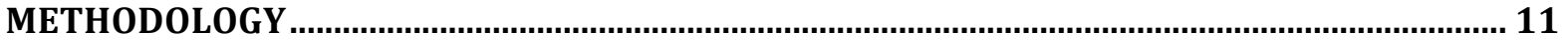

AFFORDABLE HOUSING BACKGROUND: UNDERSTANDING THE NEED FOR MORE PRIVATE

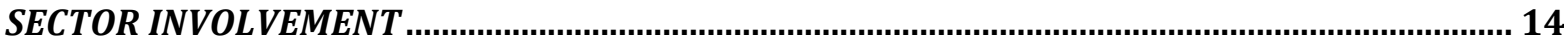

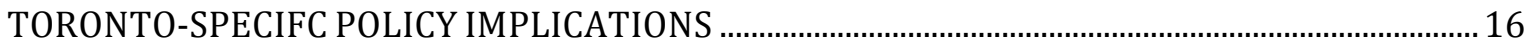

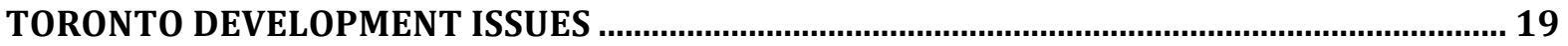

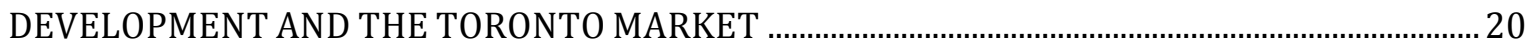

CONDOS AS RENTAL PROPERTIES

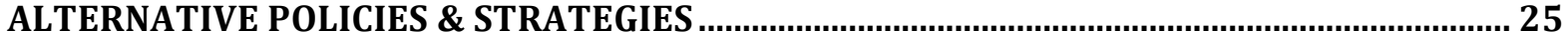

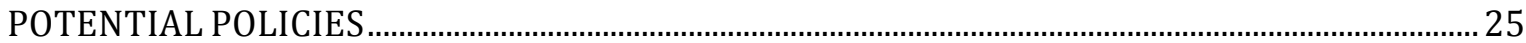

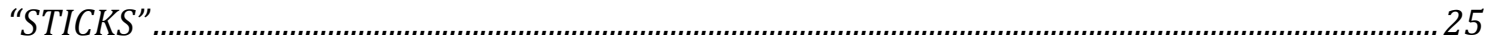

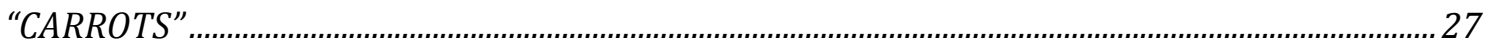

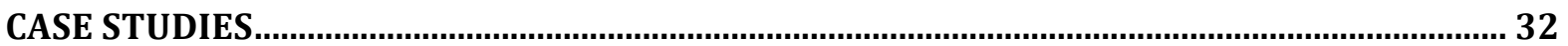

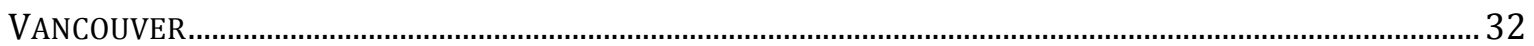

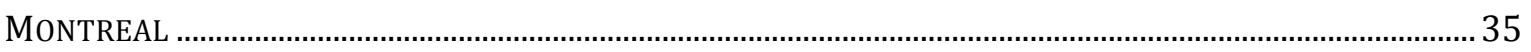

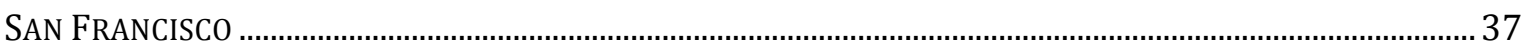

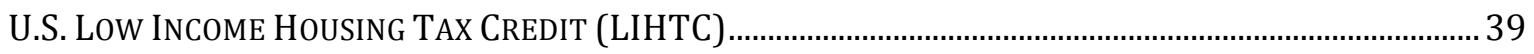

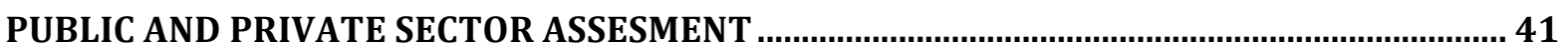

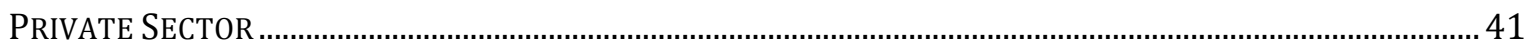

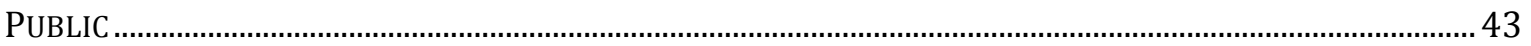

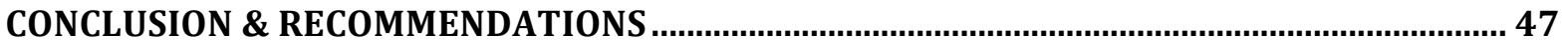

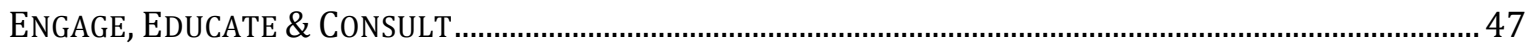

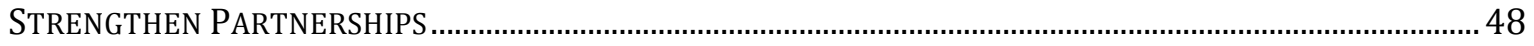

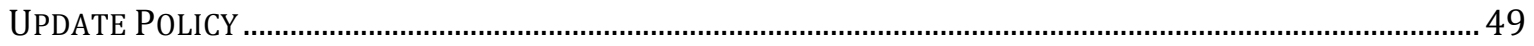

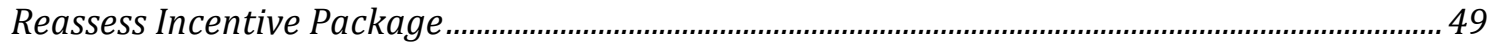

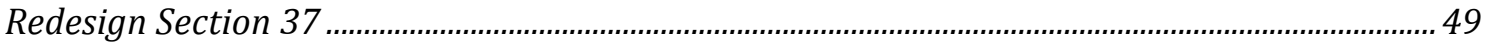

Secondary Plans \& The New Development Permit System (DPS) ................................................ 49

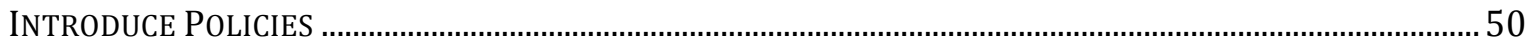

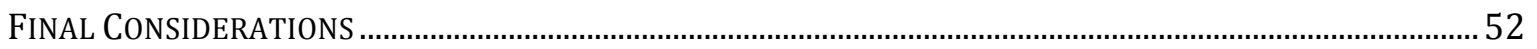

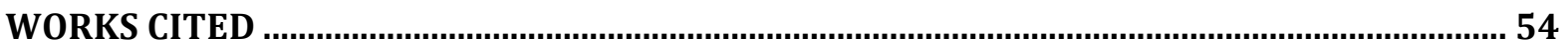

\section{LIST OF FIGURES}

Figure 1: The Housing Continuum......................................................................................................

Figure 2: The Housing and Income Continuum ....................................................................................

Figure 3: Declining Federal Social Housing Funding to Ontario .............................................................. 16 


\section{INTRODUCTION}

Toronto is currently suffering from a shortage of affordable housing options. Specifically, the decline of affordable rental housing construction and availability coupled with rising land values is a result of a systemic problem in the way the municipality and private sector are able to provide a full range of housing options to its residents. As the City of Toronto states:

Tackling the lack of affordable housing is a city-wide issue. Households living in unaffordable or unsuitable housing are found in every corner and neighbourhood of Toronto. One in five Toronto residents live in housing they cannot afford, that is too small for their needs, or that requires significant repair. (2013)

Federal, provincial and municipal policies all play a part in the regulation of the Canadian housing system. As well, the development process plays a key role, which, in Toronto, is currently struggling to encourage private sector developers to be involved in the construction of affordable rental housing. While increased upper-level government support and funding is required, it is also important for municipal policy to involve private sector, for-profit developers to contribute to producing a diverse and economically accessible housing stock in Toronto.

Affordable housing in cities is essential. There is a demonstrated need for housing that is affordable to all residents and levels of income. In "Fixing Canada's Housing Crunch" (2013), the Federation of Canadian Municipalities lists compelling data. One in four Canadians spend over 30\% of their income on housing and while average home prices have risen $67 \%$, household income in the same period only rose 13\% (FCM 2013). "The high cost of housing is Canadians' most urgent financial issue, and the single biggest risk to our national economy" (FCM 2013). Another important consideration is that while one third of Canadians are renters, only $10 \%$ of new construction has been purpose-built rental (FCM 2013). However, as noted below, many renters in Toronto obtain shelter through nonpurpose built rental properties, such as condominiums or basement suites. 
The benefits of affordable housing are numerous. There are both financial and social costs to not having an affordable housing stock. The cost of homelessness is frequently cited as a major reason to invest in housing. A 2001 report suggested that, annually, it cost $\$ 30,000$ to $\$ 40,000$ per homeless person, to offer shelter based housing services (BC Ministry of Social Development and Economic Security 2007, 4). That number continues to be cited frequently across North America (Laird 2007, 87). However, it only costs $\$ 13,000-\$ 18,000$ annually per person to cover supportive and transitional housing costs (Lewchuk 2013). Essentially, it requires less government dollars to address housing shortages than it does to support homeless shelters. Investing in housing also has a multiplier effect that stimulates the economy. Every dollar invested in housing results in $\$ 1.40$ of benefits to the Canadian economy (Lewchuck 2013 and Department of Finance 2010).

The social benefits of affordable housing, such as improved health and crime reduction, are also important to note. "In general, research supports the view that ... stable housing bring[s] substantial social benefits. Because of these extensive social benefits - what economists call positive externalities - government assistance and subsidies for the housing industry are well justified" (National Association of Realtors 2012, 2). In February 2014, the FCM released a statement asserting, "The national housing crunch and traffic gridlock are holding our cities back".

While developers are running a business and seek to make a profit on their projects, there is much room for the business and development communities to take an active roll with affordable housing. But why should private developers care? The answer is simple, and speaks to the fact that they have typically stayed away from affordable housing - they don't need to. However, it is in their interest to get involved in projects that can create returns as predictably and as quickly as possible. Affordable housing construction can provide just that. The relationship between developer, municipality and a not-for-profit housing provider is interdependent, and if done correctly, can produce results that each party desires. Ideally, developers can access capital and a quicker, cheaper development process if they are partnered with a not-for-profit (reduced development charges or fast track approvals, for example). Not-for profit organizations need developers' expertise and 
efficiency in constructing buildings. Finally, if municipal policies and taxes are favourable to this idea, municipalities can then gain the desired housing stock. 


\section{THE CASE FOR PRIVATE SECTOR PARTICIPATION IN AFFORDABLE}

\section{RENTAL HOUSING}

From the outset, renters, as well as purpose-built rental housing providers, are disadvantaged. Canadian federal policy has, since its involvement with housing, been focused on homeownership and the country's housing system "almost exclusively, relies on the market mechanism" (Hulchanski 2002, 5). Data from the 2011 National Household Survey shows that $69 \%$, or 9.2 of 13.3 million households in Canada, owned their dwelling (Statistics Canada 2011). Ontario has slightly higher rates of ownership which were reported to be over 71\% (Ministry of Finance, 2009) As the majority of Canadians are homeowners, they have more power and are able to voice opinions to governments through, for example, strong lobby groups and sympathetic ministers (Hulchanski 2003, 8). That said, the benefits to homeownership, in terms of long-term family financial stability and place making (i.e. community involvement, pride in one's dwelling), among other assets, should be acknowledged. Owners vote, renters do not. In "The Homevoter Hypothesisis", Fischel (2005) corroborates this idea by stating that "nearly every study has shown that renters participate in local affairs in disproportionally low numbers compared to homeowners" (80). In Toronto, this rings true:

Toronto tenants have had limited municipal voting rights since at least 1850, but they didn't get full rights - equal to those of homeowners - until 1972. And they still don't exercise their voting rights as often as homeowners do... in municipal elections, homeowners vote in twice the numbers that renters do. There's a political adage that "a homeowner's vote is worth two of a tenant," said Jack Layton. (Gillespie 2001)

However, this does not take away from the need to provide rental housing that is affordable. While owning a home has been shown to be linked to positive neighbourhood development and long-term household economics (National Association of Realtors 2012, 2 ), there is still much value in providing affordable rental housing. Rental housing is essential for providing residents with the ability and flexibility to have adequate shelter, according to their needs and ability. 
The rental sector plays a critically important role in Canada's housing system. Reflecting transitions in life, many tenants are young, creating new tenant households when they leave the family home. Others are older, seeking apartment living when they no longer need or want to maintain larger family homes. Similarly, immigrant households, a critical component of labour market supply, initially rent before they transition to ownership. (FCM 2012, 6)

For many low-income households, homeownership is simply out of the question, at least in the short-term. While conditions have changed since the report, the 1999 Mayor's Homelessness Taskforce Report “Taking Responsibility for Homelessness: An Action Plan for Toronto" stated that "affordable rental housing is a cornerstone in building stability and quality of life" and that "affordable rental housing and preserving existing low-cost rental housing are the key to preventing and reducing homelessness" (Task Force 1999, 125 \& 135).

In Canada, the capital gains tax, introduced in 1972, provides a compelling example of homeowner bias. The tax levies charges on the financial gain from the sale of property, among other categories (i.e. the value increase), however, owner occupied homes were and continue to be exempt, forgoing a massive revenue source for the federal government. The tax is regressive and discriminatory due to the individuals (renters) not able to benefit from the deduction. However, it does incentivize homeownership. RRSP (registered retirement savings plan) policies, through the Home Buyers' Plan, also provide another benefit to homeowners and not renters. In 1992, in response to pressure on the government to address a construction slump the federal government introduced the Home Buyers Plan. The Finance Minister, Don Mazankowski, admitted that the Home Buyers' Plan "responds to requests from industry groups, provincial governments and individuals" and that it "will support strong growth in the housing sector this year." (Hulchanski 2003, 23). The same budget cut social housing and terminated the co-op housing program. By the next budget, all social housing supply programs were terminated (Hulachanski 2003, 23). These examples demonstrate the privilege given to homeownership, the focus of federal policy as well as the type of political sway that can occur. 
We are the inheritors of a nasty and pervasive property bias in our society with roots that run deep, just as other strong biases of gender, race, and nationality still do in spite of our efforts to outlaw them. Our institutions and practices continue to embody and perpetuate the property bias, particularly in the tax system-in the subsidies given to owners but denied to renters and in many of the property tax laws that deny that renters are stakeholders in their communities. The celebration of homeownership ... stigmatizes those who don't, can't, or won't buy property. What is needed, it seems, is a civil rights movement for renters. (Krueckeberg 1999, 26)

While homeownership, and affordable homeownership for that matter, are very important pieces to the overall affordability issue, affordable rentership is just as critical (City of Vancouver 2012b). Canadian housing policy systematically favours homeownership, for both good reasons as well as political reasons tied to the strong voting power of homeowners - two thirds of Canadians (Hulchanski 2003, 5). Continuing, The Ontario Ministry of Municipal Affairs and Housing (2011), Carter (2013) and the City of Vancouver (2012b) identify a "Housing Continuum" that illustrates the different roles for a spectrum of housing types. The continuum identifies "market affordable rental" and "market affordable ownership" as having government "incentives to build or purchase" provided in order to encourage this type of housing. This illustrates the space within which this research focuses and helps to represent where affordable homeownership has received more favourable policy and funding, as described above. 
Figure 1: The Housing Continuum (Carter 2013)

\section{The Housing Continuum}

\begin{tabular}{|c|c|c|c|c|c|c|c|}
\hline \multicolumn{4}{|c|}{ Non-Market Housing } & \multicolumn{4}{|c|}{ Market Housing } \\
\hline \multicolumn{2}{|c|}{ Temporary Accommodation } & \multicolumn{6}{|c|}{ Permanent Accommodation } \\
\hline $\begin{array}{l}\text { Shelter } \\
\text { Spaces }\end{array}$ & $\begin{array}{c}\text { Transitional } \\
\text { Housing }\end{array}$ & $\begin{array}{l}\text { Supportive } \\
\text { Housing }\end{array}$ & $\begin{array}{l}\text { Non-Market } \\
\text { Affordable } \\
\text { Rental }\end{array}$ & $\begin{array}{l}\text { Market } \\
\text { Affordable } \\
\text { Rental }\end{array}$ & $\begin{array}{c}\text { Market } \\
\text { Affordable } \\
\text { Ownership }\end{array}$ & Rental & Ownership \\
\hline $\begin{array}{l}\text { Emergency } \\
\text { Shelter }\end{array}$ & $\begin{array}{c}\text { Short-term } \\
\text { accomodation } \\
\text { for people } \\
\text { in transition }\end{array}$ & $\begin{array}{l}\text { Congregate or } \\
\text { independent } \\
\text { living }\end{array}$ & $\begin{array}{c}\text { Subsidized } \\
\text { housing costs }\end{array}$ & \multicolumn{2}{|c|}{$\begin{array}{l}\text { No subsidies but } \\
\text { incentives to build or } \\
\text { purchase provided }\end{array}$} & \multicolumn{2}{|c|}{$\begin{array}{l}\text { No subsidies or } \\
\text { incentives provided }\end{array}$} \\
\hline
\end{tabular}

Carter (2013) also shows a streamlined link between income and type of tenure, highlighting the need for rental units through the idea of the "Housing and Income Continuum", which provides a simplified representation of two things. First, that affordable rentership is needed in addition to facilitating affordable homeownership as well as the likely income level of those looking or needing to rent.

Figure 2: The Housing and Income Continuum (Carter 2013)

\section{The Housing and Income Continuum}

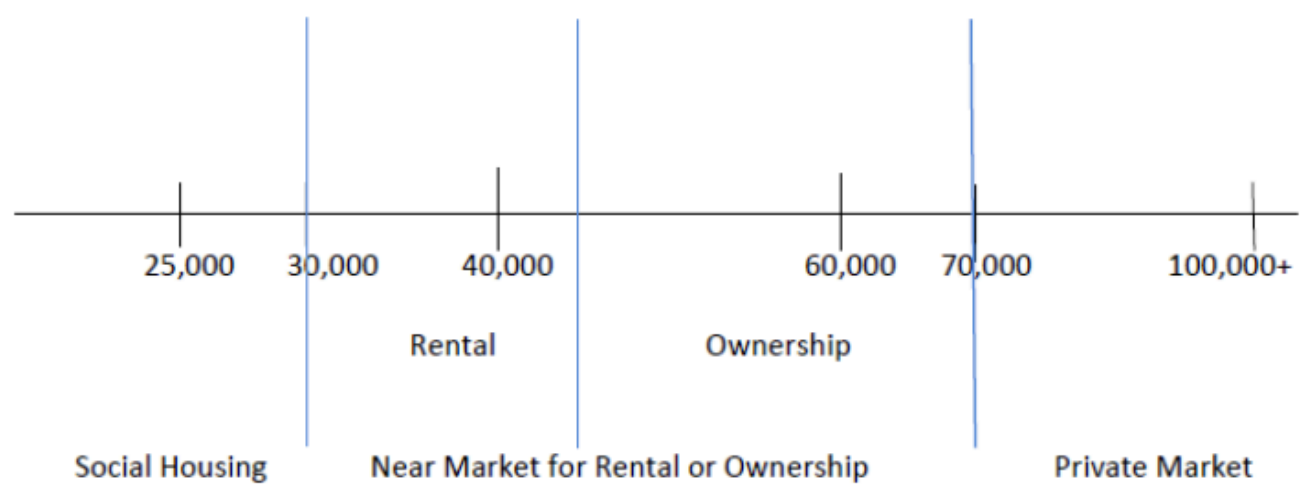


As a result of the pervasive bias to homeownership in public policy, the built form in Toronto has left gaps in the housing continuum. In attempts to address affordability issues, private, for-profit developers are being increasingly solicited to incorporate affordable housing in their developments, especially in major urban centres like Toronto. They have the expertise and efficiency to construct housing. There is a demonstrated need for private sector developers to get involved as over 95\% of Canadian households obtain their accommodation from the private market and Canada is home to the second smallest social housing sector in all Western nations (Hulchanski 2003, 3). Given this situation, the market (i.e. private developers) need to be more engaged in this process. However, as private sector developers disclosed during interviews for this research, barriers exist that make participating in affordable, purpose built rental housing, even market rental, for that matter, not economically viable. Compounded by the government's decision to not make affordable housing a priority, municipalities have been lobbying upper-level governments or considering implementing policy changes themselves, that allow cities to take advantage of the benefits associated with private sector-development (Affordable Housing Committee $2009,36)$. Some of this is already occurring. The Federation of Canadian Municipalities, through their campaign "Fixing Canada's Housing Crunch" has had 181 municipalities sign a resolution asking the federal government to develop a "new Long-Term Federal Plan to Fix Canada's Housing Crunch" which includes acknowledging that "housing costs...are undermining Canadians' personal financial security...[that] those who cannot afford to purchase a home rely on the short supply of rental units...and coordinated action is required to prevent housing issues from being offloaded onto local governments" (FCM 2013). It is the intention of this research paper to suggest the ways in which this type of participation and interaction can be coordinated. On a city-wide scale, a cooperative relationship needs to be fostered - private and public sectors - together, with separate goals (service \& profit), to address affordable housing shortages. 


\section{RESEARCH QUESTION}

This research is timely and poignant. Planners, developers and city officials should evaluate the potential of strategies that involve private sector developers in order to help address the continuing disparity between the need for, and availability of affordable rental housing in the City of Toronto. The main question of this research is: How can the City of Toronto encourage private sector participation in order to construct more affordable rental housing? What tools and strategies (financial, policy or otherwise) can be employed to promote, encourage, incentivize or require affordable rental housing construction? In the absence of adequate upper-level government policy and funding, what can be done at the local level? Both government and private sector roles and responsibilities will be discussed. The research will focus on what financial tools, programs or strategies can help or be provided to developers in order to incorporate affordable housing into their developments. How can development barriers to for-profit developers be addressed? What are the partnerships, policies or regulations that contribute to the creation of affordable rental housing development? What policies or tools, such as inclusionary zoning, have been successful in addressing affordable housing needs? This research is about starting a dialogue to foster cooperation and recommend policies and strategies that make the development process more effective at creating affordable housing while keeping on an eye on the economic impact of policy decisions.

At the core, housing is a major concern and focus of planning. In contentious urban spaces, where land use continues to become controversial and intensive, having a diverse housing stock that is accessible to people of all levels of income is paramount. However, it can prove to be a very difficult task. The provision, availability and creation of affordable rental housing should therefore be of concern to planners interested in contributing to the positive development and redevelopment of urban centres - whether it be through further regulation, deregulation or the introduction of incentives. Similarly, as Toronto grows, there is less available new land for developments, and planners and developers, alike, must therefore give specific consideration to the ability of urban centres to house all citizens, regardless of life stage or socio-economic status. Where, how and in what situation people 
live directly impacts numerous types of planning issues from economic development to sustainability, from vibrant cities, to social service availability and job opportunities. 


\section{METHODOLOGY}

This research describes and explains the potential role of public policy in encouraging, incentivizing or requiring the private sector, for-profit developers to contribute to affordable rental housing shortages in Toronto. It also explains the importance of affordable rental housing as part of a complete housing system. Incentives, whether policies or financial tools, that promote increased affordable housing production are reviewed and assessed. A mixed-method approach is used to answer this main research question and to address accompanying sub-themes. This means that both qualitative and quantitative measures are employed. Quantitative data will be used to illustrate, support or provide a counter-argument to qualitative statements and research and vice versa. Qualitative and quantitative research complement each other and therefore, stronger, more compelling results can be achieved. A combination of sources is incorporated: a targeted literature review, data collection, case studies, interviews with private developers and urban planners and policy review provides and informs the research.

To set the context of the study, the research design first involves the review of existing academic literature about affordable housing and includes themes ranging from the history of federal policy and eventual entrenchment to the current legislative context to Torontospecific development issues. This background provides the theoretical basis of the research and provides needed context concerning federal, provincial and municipal strategies and funding. Current publications offering analysis on Toronto's development process, data and issues provide the place-specific context that the research requires. This review identifies concepts, background, current trends, and potential avenues to incentivize private sector participation in affordable rental housing production.

From an understanding of both the affordable housing background and Toronto development particularities, a set of alternative policies and strategies are identified. An exploration of these potential tools explains how they function, how they are implemented and the way in which they are targeted towards private sector participation in building affordable rental housing. 
To illustrate prospective tools, case studies from Vancouver, Montreal and the San Francisco will demonstrate real-world, empirical examples of policies. While the location of this research focuses on the City of Toronto, case studies in other similarly sized and situated urban centres, will contextualize potential strategies. The research attempts to identify municipal development policies and tools that can encourage affordable rental housing to provide examples of planning practice and "on the ground" practicalities. These case studies are used to make evidence-based decisions to understand and suggest practical and applicable potential strategies.

This is where most research on this topic stops. As part of this research design, interviews are conducted to garner public and private sector opinions about the provision of affordable rental housing in Toronto. The interviews involve private-sector developers, not-for-profit housing providers and the Affordable Housing Office at the City of Toronto. This diverse participant group adds a more complete and practical understanding of the research due to the diversity of participants' occupation and viewpoints. Interviews provide insight to the particularities of development in Toronto and shed light on the potential tools that could be introduced and successfully implemented. Interviews, coupled with analysis, will assess the ability to implement potential strategies and tools. This will include an assessment of the City of Toronto's Housing Opportunities Toronto: An Affordable Housing Action Plan 2010-2020, adopted in 2009. As such, a dialogue will begin in hope of finding appropriate strategies for both the satisfaction of developers and the increase of affordable rental housing.

Lastly, a synthesis of research will provide an analysis that identifies potential actions and policies that can be employed to get private sector developers to generate more affordable rental housing. Tools will be judged according to the context of the Canadian national affordable housing system, Toronto's particular urban setting, and demonstrated applicability from case studies in conjunction with both public and private sector interviews. 


\section{GLOSSARY}

Within the context of this research, the following terms are defined:

Affordable Rental Housing: To remain relevant to provincial legislation as well as the municipal context, affordable housing will be defined in line with the Provincial Policy Statement (2014) as "the least expensive of: a unit for which the rent does not exceed 30 percent of gross annual household income for low and moderate income households; or a unit for which the rent is at or below the average market rent of a unit in the regional market area." (38)

Social Housing: An umbrella term that refers to housing that is provided, arranged and/or subsidized, at least in part, by any level of government funding. A nongovernmental service provider may be involved in the provision and / or administration of such housing programs. Supportive services aimed at maintaining a resident's ability to retain tenure may also be included.

Private Sector Developers: Development companies that operate as a for-profit entity. Like most, businesses, they look to minimize risk and maximize profit. This definition does not include Non-Governmental Organizations involved with housing (these will be referred to as NGOs). 


\section{AFFORDABLE HOUSING BACKGROUND: UNDERSTANDING THE NEED FOR MORE PRIVATE SECTOR INVOLVEMENT}

Housing, let alone the provision of affordable housing in one of the most contentious, dense and growing regions of Canada, is a multifaceted and complicated issue. Not only are housing markets ingrained in wider economic environments at national and international levels, but also it is very responsive to local context (Mah 2009, 1). As a result, Mah (2009) suggests that the provision of affordable housing is particularly difficult to address given its proven "resistan[ce] to policy responses" (Mah 2009, 1). Therefore, an examination of the Canadian housing system as well as the specific Toronto policy framework is needed when trying to understand shortages in affordable rental housing.

The landscape of housing funding has changed over the course of the last 50 years in Canada. Post-World War II policy saw large federal investment in large-scale social housing projects (Kolsteren 2012,10). Later, “a hodge-podge of initiatives came and went in the 1950s, 1960s and 1970s" (Falvo 2007, 7), which culminated in disinvestment and retrenchment from senior levels of government (Kolsteren 2012,11). Deemed as failures by the 1960s, the large-scale investments and projects soon gave way to a change in the National Housing Act in 1973, which sought to promote the production of housing through a variety of non-profit organizations and co-operatives (Kolsteren 2012,11). This marked the shift towards private and non-governmental provision of affordable housing, which continued in this direction to the present day. However, inconsistent levels of federal and provincial funding and shifting responsibility continue to exist.

The 1980s and 1990s saw continued government retrenchment and, as a result, contributed to the decrease in both public and private rental housing development (Mah 2009 , 5). Specifically, in 1993, the federal government withdrew from funding social housing completely, while Ontario downloaded the responsibility of affordable housing to municipalities "without corresponding funds" (Mah 2009, 5). This resulted in next to no new non-profit housing being built in the later part of the 1990s (Hulchanski 2002, 12). Of note as well, is the fact that under the Social Housing and Reform Act of 2000, jurisdiction 
for affordable housing was handed down to municipalities in Ontario, embodying the shift from federal to municipal responsibility (Kolsteren 2012,13). This era strongly contributed to the current housing situation in Toronto by decreasing funding and affecting the ability of non-profit and public housing providers to finance affordable housing and maintain the existing housing stock.

While the federal government committed to a housing strategy in 2001 (Falvo 2007, 11), the funding has been described as "meagre" (Hulchanski 2002, iii), pointing out that affordable housing can no longer be viewed as being solely provided and funded by the public sector. While, as Klosteren (2012, v) points out, senior government funding is a key element in the production of affordable housing, the bottom line is that the City of Toronto will need to garner private sector participation while also advocating for further upper level government subsidies.

The Toronto Community Housing Corporation (TCHC) is the agency responsible for publicly provided affordable or social housing in Toronto. It provides homes for nearly 60, 000 households (Toronto Housing Corporation 2013) while another 91, 232 are on waiting lists as of January 2014 (Housing Connections 2014). TCHC provides a diversity of residents with a variety of housing assistance, ranging from fully subsidized units, to rentgeared-to income units and affordable (below market rate) units. TCHC is funded by federal transfers, provincial contributions, regional pooling, reserve fund withdrawals and municipal taxes (Kolsteren 2012, 16). However, since senior-level government funding has dwindled and has become inconsistent, the City needs to look elsewhere to produce affordable housing, at least in part, to lessen the burden on TCHC. TCHC simply does not have enough funding to create the needed amount of housing, let alone maintain their existing housing stock. Government policy needs to take steps to give them breathing room. This can be done through encouraging affordable rental construction from the private sector. Partnerships, land and available funding must be used to leverage further housing opportunities outside of strictly public provision. The 1999 Mayor's Homelessness Taskforce Report advocated that more public investment in affordable housing was essential to attaining increased private sector participation stating "'the need for public 
investment in low-cost housing could not be clearer" (Task Force 1999, 14). Essentially, government subsidies, be it in the provision of land, tax easement, financing or cash, are necessary to make the cost of affordable housing feasible for private sector development.

Recently, the Canadian and Ontario governments have adopted the Canada-Ontario Affordable Housing Program (AHP), which has marked some areas of optimistic improvement. Since 2010, developers have expressed positive experiences with the program, especially with the "turnkey approach" (Black 2012, 22) which provides grants and other financing to partner a developer with an NGO, where the developer constructs the building, assumes the risks and acquires a reasonable profit before handing the building over to the NGO who will maintain the affordability. However, federal funding to social housing, as demonstrated by Chart 1 , has been steadily decreasing and is set to eventually remove all federal dollars to social housing, again demonstrating the reluctance of upper level governments to support affordable housing.

Figure 3: Declining Federal Social Housing Funding to Ontario (Ministry of Municipal Affairs and Housing 2014)

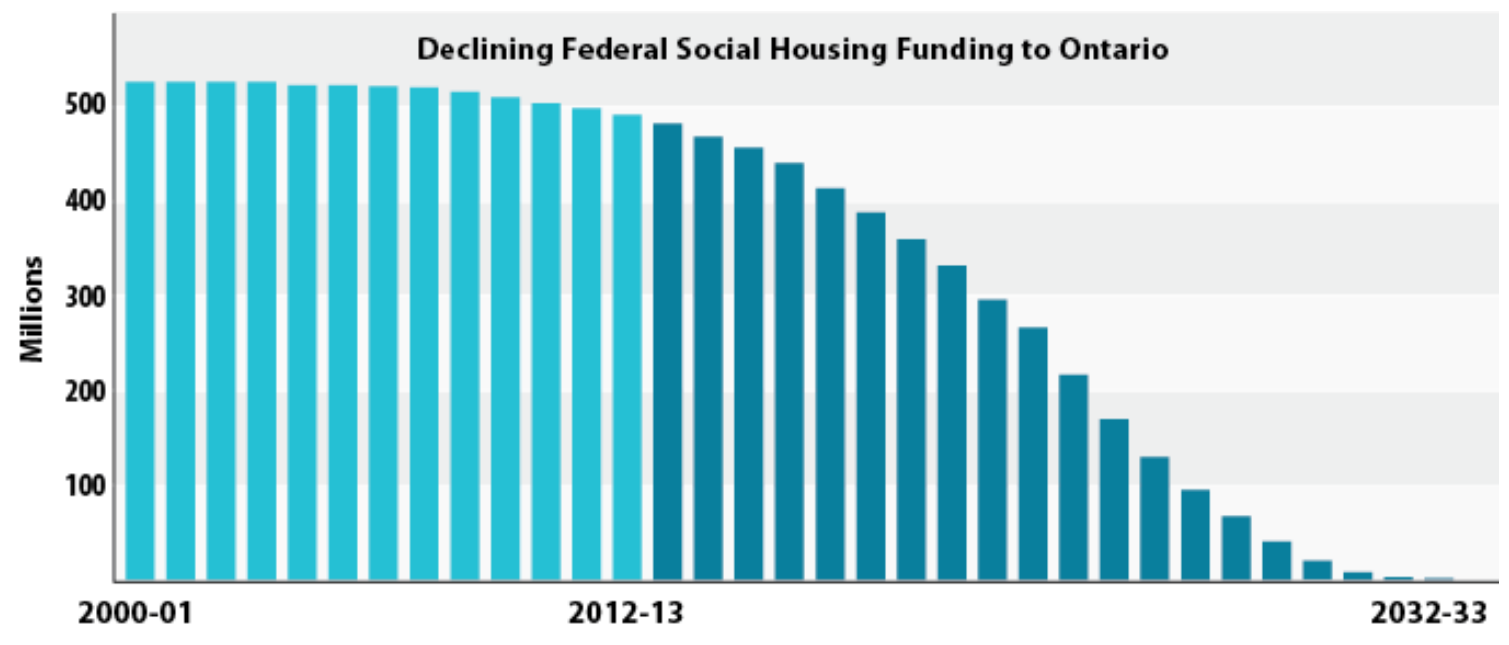

\section{TORONTO-SPECIFC POLICY IMPLICATIONS}

The legislative context is also important for understanding affordable housing shortages. For Toronto, housing policies in the Provincial Policy Statement (PPS) are manifested 
through the city's Official Plan. While the 1989 PPS called for a 25\% target for affordable housing in new developments (Mah 2009, 8), the 2006 and current 2014 PPS do not include any concrete targets (Municipal Affairs and Housing 2014). However, the current PPS provides the authority to municipalities to "establish and implement minimum targets for the provision of housing which is affordable to low and moderate income households" (Municipal Affairs and Housing 2014, 1.4.3.a). The Growth Plan for the Greater Golden Horseshoe directs municipalities in a similar fashion by reinforcing Policy 1.4 .3 and stating that municipalities will develop housing strategies that "meet the needs of all residents, including the need for affordable housing" (Ministry of Infrastructure 2006, 3.2.6) but goes to place emphasis on meeting intensification goals. The Growth Plan focuses on the idea of complete communities, which, among other things, indicates both the need for affordable housing in municipalities facing growth pressures as well as the idea that affordable housing is part of a larger picture of creating communities that meets people's need through their lifetime.

“Complete communities meet people's need for daily living throughout an entire lifetime by providing convenient access to an appropriate mix of jobs, local services, a full range of housing and community infrastructure and including affordable housing..." (Ministry of Infrastructure 2006, 47)

"Investment in community infrastructure - such as hospitals, long-term care facilities, schools and affordable housing - should be planned to keep pace with changing needs and to promote more complete communities. In the case of housing, there is an underlying need for affordable housing in many municipalities that heightened by growth pressures" (Ministry of Infrastructure 2006, 23)

The City of Toronto's Official Plan, however, does not make any reference to a percentage target (except in the Large Sites Policy). Over the course of the plan, the similar refrain of “encourage[ing] GTA municipalities to provide a full range of housing types in terms of form, tenure and affordability and particularly encourage[ing] the construction of rental housing in all communities" (City of Toronto, 2010, 2.1.1.f) is repeated. Nevertheless, an emphasis on rental housing creation has the potential to provide the necessary legislative basis to suggest that type of housing production be a priority of the City. What is important 
to understand is that these policies are not prescriptive and their implementation is "fluid and contextual" (Klosteren 2012,16). This means that while they provide the legislative backing for affordable housing production, there is nothing that ensures that such development happens to the extent that it is needed. Herein lies the issue. The municipality cannot address the problem alone, nor is there a legislative framework or upper-level government funding to have the private sector contribute at the level needed. 


\section{TORONTO DEVELOPMENT ISSUES}

As this section demonstrates, much development in Toronto is yet to match up with the needs of many Torontonians. The mis-match points to systematic problems with how Toronto provides a full-range of housing. In 1999, the Mayor's Homelessness Taskforce Report pointed to several issues Toronto was facing in terms of affordable housing. These issues have remained pervasive. The report pointed to the rising portion of renters that faced affordability issues, increasing numbers of low-income households as well as the gap between supply and demand of affordable rental housing (135). The report, now 15 years old, also pointed out that the number of households that are paying more than a "reasonable proportion of their income [is]...large and increasing" (138). The demand for affordable housing has continued to rise. In 2006, 598, 120 households, or $33.4 \%$ of all Toronto households, spent more than $30 \%$ of their income on shelter (Ministry of Finance 2009). Compounding this issue is that there has been a proportional loss of affordable units (FCM 2012, 8). Since purpose-built rental construction over the past 15 years has only accounted for $10 \%$ of all housing starts (mentioned above), this low supply has placed upward pressure on rents, pushing many units beyond what can be deemed affordable (FCM 2012, 7). There are a number of factors that have played a part in the lack of rental production. Rent regulations, taxation on rental investment income and, most of all, the increased costs of new construction in cities means that income from rental investments do not provide a reasonable rate of return (FCM 2012, 7). Condominium development is also very lucrative. "This disincentive to invest in rentals is in large part attributable to the impact of condominium development, which sets the price for multi-residential land" (FCM $2012,7)$. Rent regulation can also be attributed as a factor to increased condominium development.

The current affordable housing context in Toronto suggests that affordable housing is a problem that continues to grow worse. Since 2009, 21 urban centres in Canada, including Toronto, have seen a trend in decreasing vacancy rates. Toronto's 2014 vacancy rate for all rental units is projected to be 1.8\% (CMHC 2013d, 4). It was 3.2\% in 2006 (CMHC 2006, 14). Similarly, the waiting list for TCHC and other affordable housing providers (such as the 
Kehilla Residential Program), called Housing Connections, reported having a waitlist of 67,083 households in 2007 (Housing Connections 2007, 1), while in 2013 it had 90,990 on the list (Housing Connections 2013, 2). The City of Toronto has reported that households can wait up to 12 years on this list (Affordable Housing Committee 2009, 31). Between 2012 and 2013, average rent for apartments increased by 3.1\% (CMHC 2013b, 1). "In the City of Toronto, projected demand for rental homes is expected to outpace supply, due to a growing proportion of young people, seniors and in-migration influencing where people choose to live and work." (Burda 2013, 9). These factors all clearly demonstrate that affordable housing is both a pressing and a growing issue in Toronto.

\section{DEVELOPMENT AND THE TORONTO MARKET}

Toronto is faced with a set of challenges when attempting to boost its affordable rental housing stock. Development and construction costs, the cost of land and the length of time associated with getting projects off the ground can be extremely high. As a result, the cost of land and construction in the city can be prohibitive to creating affordable housing (Wellesley Institute 2005, 3). Market demand and prices are also high and are either remaining constant, or rising (CMHC 2013) because the cost of land is capitalized in sale or renting price.

CMHC reports that the average 2-bedroom apartment rent is about $\$ 1,200$ per month or $\$ 1,000$ for a 1-bedroom (CMHC 2013). As calculated by the Wellesley Institute (2005), to afford such a rent, a household would need to have an income of over $\$ 40,000$, when in 2005 , they calculated that to afford a rent of $\$ 1,060$ per month, an income of $\$ 42,400$ would be needed (3). The same report put the number of households with an income of less that $\$ 40,000$ at 382,000 or over $40 \%$ of the City of Toronto, a number that had continued to increased since 1991 (Wellesley 2005, 3). The development of affordable housing in Toronto has also suffered since the 1990s. Since federal disentanglement and the subsequent provincial downloading to municipalities, development of new affordable units stalled. Between 1995 and 2005, less than half of the city's 44 wards had any new affordable units constructed (Wellesley Institute 2005, 3). Where over 2,000 units were created each year between 1990 and 1994, the later part of the decade only saw a total of 
1,435 units added (Wellesley Institute 2005,3). When the number of people requiring affordable homes is increasing and the number of new units being constructed is decreasing, there is a serious disconnect between market realities, public policy and funding.

For many, homeownership, even through affordable homeownership programs, can be out of the question. While affordable homeownership programs assist with boosting down payments or second mortgages, a prospective participant in the program still needs a significant amount of cash to start. Options for Homes, a Toronto based affordable homeownership builder and provider, typically requires around a 5\% down payment (with Options covering the rest of a $20 \%$ down payment to avoid paying mortgage insurance) (Options for Homes 2014). That means that for a $\$ 150,000$ condo, the buyer would still need to come up with $\$ 7,500$ as a down payment. As a result, "rental demand is growing in the GTA...half this demand is for units that rent at below-market levels" (Task Force 1999, 139). There is a clear need for an increase in affordable rental units.

The private sector is not able to meet the low-income housing needs without some form of government subsidy (FCM 2012,3). While in recent years there has been an increase in affordable housing construction, the "patchwork of funding and programs at the federal, provincial and municipal levels has failed to deliver the numbers of new affordable homes that are desperately needed" (Wellesley Institute 2005, 3). As a result of the legislative framework and senior-level government funding shortages, the City of Toronto has attempted to leverage land use and planning tools to address affordable housing shortages. Most have come from Section 37 of the Planning Act as well as the Large Sites Policy of the Toronto Official Plan. The Large Sites Policy is yet to produce any affordable housing, however, the Hines and Tridel East Bayside development is set to sell $20 \%$ of their units (between 70 and 75 units) to the City of Toronto as affordable units (Moosebraaten 2013). This would be the first use of the policy. Because of the size requirement, it would not apply to most developments in Toronto. Both of these policies are, inclusionary housing policies in the sense that they can require the provision of affordable housing as a condition to development approval. The strength of these tools, however, must be considered. 
Section 37 is an ambiguously worded policy in the Planning Act that states that for developments seeking an increase to allowable height and density according to the municipality's zoning, they must provide "community improvement facilities, services or matters" (Municipal Affairs and Housing 1990, 37) in return. Essentially, that is to say, a developer must secure community benefits for the neighbourhood where the development is located. The policy also allows "cash in lieu" payments to the local municipality that would be put towards community improvement facilities, services or matters. The Large Sites Policy has a cash in lieu option is as well (City of Toronto 2010, 3.2.1.9). The overall effectiveness of these policies at producing affordable housing has been largely criticized (Mah 2009, 9). Community benefits are negotiated by ward councillors and developers on an ad hoc basis and the type of benefits that are obtained vary according to the priorities of local councillors (Mah 2009, 9). Since affordable housing is just one of the community benefits that can be agreed upon, it is not provided with every development. Often, other benefits like parks or contributions to the art and culture are more accepted by local neighbourhoods compared to affordable housing because housing is seen as "benefitting a limited range of residents" (Klosteren 2012,19) while parks, community and recreation centres or public art are seen as benefitting the whole community. NIMBY attitudes can also present negative perceptions of affordable housing. Cash in lieu has also been highlighted as a loop-hole for developers, who would rather pay for their density bonus, than deal with providing community benefits (Mah 2009, 9). Consequently, Mah (2009) contends that Section 37 and the Large Sites policy "are not effective tools at generating affordable housing" (Mah 2009, 9), citing that since 1983, only 18.9 percent of Section 37 agreements involved affordable housing (Mah 2009, 9). From this, a reasonable conclusion is that Toronto must develop or adjust policy tools to create enough affordable housing for its population.

There are significant affordability issues spread throughout the Greater Toronto Area, none more severe than in the City of Toronto (City of Toronto 2013). Section 37 agreements are concentrated in Toronto because that is where the development market generates additional density rezoning. The growth of non-governmental organizations involvement in 
affordable rental housing provision was, not only in response to a lack of private sector development of rental units, but up until 2000, has also "compensated for the virtual disappearance of private-sector rental construction" (Task Force 1999, 144). In Toronto, it is clear that a policy change to further incentivize or require the involvement of the private sector is needed to reflect the need and demand for affordable rental housing.

\section{CONDOS AS RENTAL PROPERTIES}

An important part of Toronto's housing rental stock are condominiums. Condominium development has dominated the Toronto multi-unit scene for the past four decades, in part due to intensification policies and as response to rent review legislation. For this research to be useful, the role the condominium market and subsequent condominium rentals that occur as a result, must be acknowledged. As a response to market conditions and low interest rates, condominium construction has played a large role in the decline of purpose built private rental buildings, which, has therefore constrained the supply of rental housing. The housing market in Toronto has also resulted in condominiums as investment properties, leading many units to be rented out, either individually, or by a professional rental management company (Urbanation 2014). In 2013, a total of 19,689 condo units were rented through the Multiple Listings Service (MLS)(Urbanation 2014), which does not include listing services, such as "Craigslist". As a result, condominiums now account for about $20 \%$ of all rental apartment supply in Toronto (Urbanation 2014). "The increase in investor involvement in recent years and strong demand among renters has made rentals the fastest growing segment of the Toronto condo market." (Urbanation 2014).

However, the average monthly rental price for condominium rentals was $\$ 1,829$ (Urbanation 2014), which suggests that most rental condo units are being rented for well above the market average for all rental units $(\$ 1,200$ per month for 2 bedroom [CMHC 2013a]). Therefore, the rental condominium market is not directly serving the city's residents for whom housing affordability is an issue. However, the increase in the supply of units must be considered as having a positive impact. The portion of households that obtain housing from the condominium market, let alone the market it self, must be taken into consideration when debating policies that are aimed at increasing housing 
affordability. This is because policy-makers could choose to consider subsidizing or incentivizing condominium investors to provide affordable units or loosen development restrictions to bring down costs, which could lead to increased affordability. 


\section{ALTERNATIVE POLICIES \& STRATEGIES}

This section explores existing policies that provide alternatives or additions to current policies in Toronto that may incentivize or require increased private sector participation in building affordable housing, including affordable rental housing. Policies will be explained and the way in which the policies engage the private sector will be described.

Policies that can engage private sector developers in the construction of affordable rental housing can be divided into two categories: "carrots" or "sticks". "Carrot" policies refer to the idea of incentivizing, or providing some sort of attractive reason (i.e. a tax break or an expedited development approval) to a developer to decide to become involved with, in this case, affordable rental housing. "Stick" polices refer to the implementation of a policy that requires, or forces, (i.e. inclusionary zoning or a mandatory financial contribution) a developer to provide something, in this case, affordable rental housing. The following is a list of policies that have been used across North America, in one way or another, to attempt to create affordable housing.

\section{POTENTIAL POLICIES}

\section{"STICKS"}

\section{Housing Trust Fund}

An affordable housing trust fund is one way of requiring private sector developers to contribute to affordable housing. An affordable housing trust fund works by collecting mandatory contributions from all developments of a pre-determined type (a percentage of uplift value, for example could be used). Funds would be dedicated to the provision of affordable housing, as opposed to being shared among other community benefits. Administered by a housing department such as the Toronto Affordable Housing Office, the housing fund would then be able to "offer a blend of grants and loans and support housing initiatives from new construction to capital repairs and energy upgrades." (Shapcott 2014a). While developers would play an indirect role in providing affordable housing, the trust fund would be in a position to provide the financing or subsidy that would incentivize private sector developers to get directly involved (by applying for the funds or land made 
available by the increased funding). The housing trust fund would be able to stipulate what type of developments qualify for funding and be able to control what is constructed. In this way, a housing fund would be able to ensure purpose-built rental buildings were built.

Another benefit of creating an affordable housing trust fund is that it would be able to administer a community land trust, which would secure public land or purchase available land from the contributions to the fund. A community land bank could therefore offer attractive long-term land leases for affordable housing development (Shapcott 2014a). However, this type of arrangement would need to be carefully managed and monitored to avoid negative outcomes.

\section{Exactions Fees}

Exaction fees are taxes on new commercial, retail or industrial projects within a certain municipality or ward, that could be directed to a specific fund for, as an example, the creation of affordable housing. Exactions can be called "conditions" or "impact fees" and can be delivered in various ways, either monetarily or physically (University of Florida Law $2014,1)$. They can be in the form of "infrastructure building, cash payments to the local government, dedications of land for public uses, conditions on future land use, restrictions on alienation, or other restrictions or burdens on the permit applicant" (University of Florida Law 2014, 1).

Exaction fees would be another way to fund an affordable housing trust fund but in this case, developments of all kinds would be contributing. As well, depending on how the exaction fee policy is designed, it could be collected on ward-by-ward basis and fund affordable housing in each individual ward. This would enable municipalities and ensure developers and businesses that contributions would go to the immediate areas of their projects. However, this has the potential to facilitate uneven provision of affordable housing throughout a municipality since the areas with the most development and business activity would receive funding.

The best known type of exaction fees are called Linkage Fees, which seek to 'link' the 
effects of non-housing development to local housing options. Linkage fees look to "offset the adverse impact of major new commercial and other job-generating developments on the local housing conditions " (Sherlowski 1999, 2). What is of interest is that linkage fees look to have private businesses, aside from residential developers, who, "as various reports have shown...directly and indirectly create many new low-paying jobs" (Sherlowski 1999, 2 ), contribute to the process of funding and constructing a full range of housing since the same developments "attract new households often unable to find affordable housing" (Sherlowski 1999, 2).

\section{Inclusionary Zoning}

Inclusionary zoning requires a certain percentage, typically between $10 \%$ and $30 \%$, of units in a given development to be created as affordable units, either for rent or purchase. Affordability needs to be guaranteed for certain length of time, typically around 20 years. There are a variety of inclusionary policies that could require the units to be on-site, allow them to be off-site or allow cash in lieu contributions. Most inclusionary zoning policies are mandatory, however, there are voluntary inclusionary zoning models as well (Mah 2009, 36). Other inclusionary policies can include conditional requirements according to funding. For example, Chicago's inclusionary policy is $10 \%$ of units for private developments, but increases to $20 \%$ when the city provides any financial assistance (Wellesley Institute 2010, $3)$.

Inclusionary zoning is an increase in regulation and therefore has several champions, detractors, successes and failures. The success of inclusionary zoning policies can depend on various municipal situations, such as hot or cold housing markets, political will and community engagement (Mah 2009, 46).

\section{“CARROTS"}

Many incentives that can attract private sector developers to building affordable rental housing come in the form of reducing either hard or soft costs of development. Overall, "carrots" seek to make developments more 'efficient' by reducing 'inefficiencies' in the development process. That is to say, things that are cost-prohibitive, or costly in time 
contribute to making projects more expensive and therefore more inefficient. "Carrots" attempt to reduce that burden to an appropriate threshold that, in turn, increases the feasibility for private sectors developers when assessing whether or not a project is a good investment. Private sector developers generally prefer these policies.

\section{Reducing Soft Costs}

\section{Streamlining the development process}

The municipal approval process can be time consuming, leaving developers to wait for months, even over a year in some cases, to have developments approved. Streamlining environmental assessments, planning and pre-development processes can be a significant cost saving measure for a developer as it not only reduces costs but also reduces the risk of increased capital costs that result from interest rate increases that occur during long approval wait times (Black 2012, 30).

\section{Reduce or remove Development Charges}

Development charges are fees that are paid by developers to the municipality, which are meant to contribute to the cost of needed infrastructure improvements that come as a result of adding more density to an area. Development charges for a two-bedroom apartment unit, in 2014, are $\$ 15,265$ while a detached home is charged $\$ 24,298$ (City of Toronto 2014a, 1). Reducing or waiving development charges has the potential to significantly impact a private sector developer's ability to make financial sense of building affordable housing. In Ontario, Education Development Charges and GO Transit Development charges are also levied and are additional charges to the standard development charge.

\section{Waiving fees}

Aside from development charges, other fees contribute to increased construction costs. Planning review fees, building permits, engineering and servicing, property tax, Hydro or Utilities Fees, Parkland Dedication, Tarion Enrolment Fee, CMHC Mortgage Insurance, Section 37 contributions, Harmonized Sales Tax and Land Transfer Tax are all possible 
additional fees that developers may encounter during the development and construction of a property in Ontario (Altus Group 2013, 19). Together, but not including Development Charges, these fees can cost well over $\$ 50,000$ per unit in the City of Toronto (Altus Group 2013 ,24). Considering waiving, or discounting these fees or taxes can help bring costs down as well, and can be considered an incentive to developers when reduced or removed.

\section{Provide loan guarantees}

Loan guarantees are when, in this case, a municipality provides backing to a developer's loan that is financing the construction of a building. Essentially, the municipality is providing assurance to the lender that if the developer defaults on the loan, the municipality will pay. In this way, loan guarantees are able to reduce the cost of borrowing by allowing lower interest rates, which reduces overall expenditure requirements for constructing a building (Black 2012, 31).

\section{Tax incentives}

Tax based incentives are tax deductions, credits or refunds received for contributing to a public priority or issue, such as affordable rental housing. In Canada and the United States, most public funding for affordable or social housing comes in the form of tax or grant measures (Black 2012, 31). Currently however, Canadian federal and provincial programs are all grant-based (Black 2012, 31). Another type of tax related policy incentive is reduced or forgone property tax, which reduces on going operating expenses (Black, 31).

\section{Reducing Hard Costs}

\section{Update Building/Construction Regulation}

Changing building and construction requirements can also affect affordability. Minimum unit size, building materials or parking requirements, for example can impact overall cost of construction. Building regulation currently does not allow for any buildings over four stories to use wood frame construction, due to older safety concerns. However, new methods and materials are safely allowing buildings of five or six stories to be constructed with wood framing (Black 2012, 30). Wood frame construction offers as much as $40 \%$ cost 
savings than concrete construction (Black 2012, 30) and as such would reduce cost of construction, making it more feasible for private sector developers to become involved. The Ontario government announced plans in March 2014 to amendment the Ontario Building Code to allow for wood frame construction of up to 6 stories (Landau 2014).

\section{Access to land}

Cost of land, especially in urban centres like Toronto, can be a significant barrier to private sector development. Being able to reduce the expenditure required to acquire land can be a huge incentive for developers to build affordable housing. There are few ways to do this. Providing public land at no cost is the best way, however, in Toronto, the sale of public land is expected to generate revenue for municipal coffers (Black 2012, 29) or to be conveyed to not-for profit groups. However, there are ways to provide land at a below market price that would otherwise be inaccessible for not-for profit entities. While risky, a proactive municipality could purchase land in gentrifying neighborhoods. As well, building above public facilities, such as community centers or schools has been suggested in Toronto (Oleson 2014). Long-term land leases have also been shown to reduce upfront costs (Black 2012 , 29). Conversely, from an upper-level government perspective, changing subsidy levels to reflect higher land costs in urban centres would also increase the accessibility of land (Black 2012, 29). It should be noted that given the strength of the Toronto housing market, caution should be taken when providing developers with subsidized land.

\section{Density Bonusing}

Overall, Canada has a reputation of procuring private sector participation through density bonusing: agreements that provide additional residential development rights in exchange for the provision of affordable units (among other community amenities or public goods) or in-lieu payments (Scherlowski 1999, 10). Density bonuses can be for a suite of community benefits (like Section 37) or have one municipal interest as the beneficiary. Incremental Bonusing, which has been used in the United States, is a type of density bonus that increases up to a certain maximum as the developer increases the amount of affordable units above the original requirement (Scherlowski 1999, 11). Another type, used in New York, called Incentive Zoning, refers to a density bonus awarded to developers 
who voluntarily contribute affordable units, through the transfer of development rights from historical buildings within a certain zone (Scherlowski 1999, 62).

\section{Land Value Capture (TIFs and TIEGs)}

Another way of raising capital to subsidize affordable housing construction is through the use of establishing "Tax Increment Financing" Zones or "TIFs”. Extensively used in Latin America and the United States, TIFs allow for municipalities to capture the increase in land values of a pre-determined area in order to finance capital expenditures towards public infrastructure or other public goods (Amborski 2013). This type of revenue may pose challenges to implement in Canada, since property is seen as a investment, however, the rationale is that since value increases can be associated with public improvement, that the public should recoup some of the benefit (through the increase of land values), not just landowners. However, TIFs take longer to come full circle, economically.

TIFs would generate participation from private sector developers in the same way as a housing trust fund. Through the accumulation of revenue as a result of a TIF zone, funds would be made available to qualifying affordable housing developments. A rental component could exist as part of the criteria for evaluating project applications. TIFs are used in the United States as a community building tool, and affordable housing is one of the permitted investments. However, TIFs have not been applied in Toronto.

Tax Increment Equivalent Grants (TIEGs) are used by the development sector to cover the costs of redevelopment and rehabilitation of brownfields. They have been referred to as "Rehabilitation and Redevelopment Grants" and are similar to TIFs as they provide "financial assistance equal to all or a portion of the municipal property tax increase (increment) following the completion of a project which has resulted in an increase in the assessed value of a property" (Ministry of Municipal Affairs and Housing 2012). TIEGs have been used in Toronto and represent an established way to decrease expenditures on land costs. They are only applicable to brownfields. 


\section{CASE STUDIES}

The following case studies identify similar municipalities and their development policies that encourage affordable housing in order to evaluate the potential for new policies to be successful in Toronto. The municipalities of Vancouver, Montreal and San Francisco will be evaluated. All of these cities are facing upward pressure on their housing market and are experiencing affordability issues. As a result, these cities have introduced different types of policies that seek to address affordability concerns and to create more affordable units. Policies are aimed at a mix of affordable rental and ownership units.

\section{Vancouver}

The City of Vancouver provides a good comparison to the City of Toronto due to several similarities. Vancouver is described as the "tightest rental market" in Canada, having a vacancy rate of $0.9 \%$ (City of Vancouver 2014), a vacancy rate lower than in Toronto. More than half of the city's residents rent, placing further strain on the lack of affordable and moderately priced rental options available in the city (City of Vancouver 2014). Vancouver, and its current mayor, Gregor Robertson, however, have made affordable housing a clear priority (Klostenran 2012,28), that targets the supply of rental housing, both market and affordable, through a suite of policies.

The Province of British Columbia did not, as Ontario did, download the responsibility of social housing to municipalities. However, Vancouver has a mandatory $20 \%$ inclusionary zoning policy (Klostenran 2012, 26 and Mah 2009, 31). As well, Vancouver, overall, has more inclusive policies and programs such as Development Cost Levels and Community Amenity Contributions that also contribute to affordable housing creation (Klostenran 2012, 26 and Mah 2009, 31). Vancouver's 20\% policy functioned with the existing federal and provincial funding, prior to the federal withdrawal (Klostenran 2012, 28). The city has since responded by adjusting the policy with moderate success, in part due to the addition of a successful payments-in-lieu program, which deals directly with affordable housing, not just community benefits, in which land designated as affordable housing is converted to market rentals (Mah 2009, 30). In all of these cases, the funding has been able to be used to secure affordable housing elsewhere in the neighborhood or adjacent neighborhood (Mah 
2009,30 ). However, the lack of federal dollars limits the city's powers to provide affordable housing. It should be noted that there is no Ontario Municipal Board-like appeal process, which can make developers more interested in successful negotiations with the city (Mah 2009, 27).

An inclusionary zoning policy is not the only municipal policy that attempts to increase the supply of affordable housing in Vancouver. As mentioned above, the city has designated land for affordable housing development as well, which, while similar to the "Housing First" policy in Toronto, makes explicit designations for affordable housing, in conjunction with the adapted in-lieu policy that facilitates the funding of such sites. In October of 2012, the city approved an "Interim Rezoning Policy for Affordable Housing" which is "aimed at encouraging innovation and enabling real examples of affordable housing choices on major streets related to transit" (City of Vancouver, 2013, 1). This temporary rezoning facilitates the approval of 20 development proposals that are between three and six stories, on avenues or arterial streets, have a "strong level of affordability" and are 100\% rental units, or ownership available at $20 \%$ below market rate (Vancouver 2014). After the first 20 qualifying projects, city council will review the program and consider extending the limit.

Vancouver has also targeted the rental housing supply directly. With the idea that purposebuilt rental becomes more affordable over time, the city has engaged in policies that accelerate and encourage purpose built rental housing (City of Vancouver 2012a, 7). Again, the city has identified a need stating that "With a growing population, limited increases in income and limited new supply of purpose-built rental housing in recent decades, the need for suitable housing choices for low and moderate income households has grown significantly" (City of Vancouver 2014). As part of the 10-year Housing and Homelessnees Strategic Plan, an array of both short-term and long-term policies works in unison to address housing affordability and rental availability.

To begin, the "Rental 100: Secured Market Rental Housing Policy" seeks to encourage the construction of purpose built rental buildings by reducing parking requirements, waiving Development Cost Levies (DCLs) (similar to Development Charges), slightly accelerated 
application processing (rezoning and development permit applications processes occur simultaneously) and relaxing unit size requirements for developments that are $100 \%$ rental housing for at least 60 years or the life of the building, which ever is greater (City of Vancouver 2014). Affordability can then be achieved through "location, reduced parking, modest size, limited on-site common amenities, level of finishing and other design considerations" (City of Vancouver 2012b, 3), however, there are no explicit requirements for affordability.

The "Short Term Incentives for Rental Housing" or STIR is a policy that provided incentives to purpose built rental housing for a fixed short amount of time. It ran for two and a half years ending in 2011 (City of Vancouver 2014). It offered similar incentives as the "Rental 100 " now offers as well as a few others. On top of reducing parking requirements, waiving DCLs and relaxing unit size requirements, the STIR program allowed for further density bonusing, expedited approval process and rental property tax assessment (on stratas that have a housing agreement limiting it to rental, essentially reducing property tax). A total of 1,651 units were produced through this policy. This represented a significant increase of privately initiated market rentals from 80 units a year to 550 units a year (City of Vancouver 2012a, 21). However, while affordability was not a direct requirement of the program, STIR increased the overall supply of rental housing and provided units for moderate incomes and households whom are financially unable to pursue affordable homeownership (City of Vancouver 2012a, 29).

These policies have enabled the private sector to build and increase the supply of secure market rental housing and provide housing that is affordable to moderate income households. Affordability is considered in all policies. However, the city found that it was unable to directly target those in core housing need through incentive based programs such as "Rental 100" and STIR due to the subsidies required to make it financially viable for developers (City of Vancouver 2010,3).

Key lessons from Vancouver are numerous. Vancouver utilizes a diverse array of policies, both regulatory and incentive based, long and short term, that are able to target key 
priorities, like supply of rental units. The city demonstrated success in increasing rental unit construction through short-term policies as well as with the interim bylaw, which capped the amount of applications. The City has also chosen to target affordability and rental supply together as well as separately and have specifically identified and qualified the importance of both issues. The success of introducing a mandatory zoning bylaw is also laudable. As well, the City's Strategic 10-year plan sets aggressive targets for social and rental housing (City of Vancouver 2012b, 2). However, all policies in Vancouver must be understood as part of a political and legislative atmosphere that is more supportive than Toronto's development process, including the OMB, different development and community contribution structures and provincial support. When discussing "deeper levels of affordability, such as housing for core-need", the City suggested that in doing so, it would be "using its limited tools to address a responsibility traditionally addressed by the Province" and went on to state that "a collaborative government approach with funding and programs from senior levels of government is needed to achieve housing at below market rents" (City of Vancouver 2010, 3).

\section{Montreal}

Montreal has been forced to take a different approach in the provision of affordable housing. A city that, like Toronto, amalgamated municipalities has now deamalgamated and given local land-use control to the separate 19 boroughs. As a result, affordable and social housing programs, policies and funding are administered at the city-wide level, but must be put into practice through the boroughs, which have control of over local planning and development approval (Wellesley Institute 2009, 1). Like Vancouver, the province has much more involvement in housing affairs, funding and does a better job of having a diverse set of funding options and partnerships (Thibert 2007, 28). The Province of Quebec and the City of Montreal have a variety of government (provincial and municipal) agencies, initiatives, programs, private sector and non-profit groups who provide different housing solutions and programs (Klosteren 2012, 30). As a result, cross-provincial or municipal comparisons are challenging, but importantly, "the diversity of players creates a level of resiliency and adaptability, with government, non-profit, and private sector organizations able to involve themselves at different junctures" (Klosteren 2012,31). 
Regardless, Montreal demonstrates a noteworthy analysis and comparison. Like both Toronto and Vancouver, the city was in need of a response to "a number of pressures: the rising house prices in the city together with the growing demand for affordable housing, the depleting supply of city-owned land for affordable housing, and the uncertain future availability of social housing funding" and thus "prompted a search for ways of involving private sector in providing affordable housing, and of securing sites for social housing on privately-owned lands" (Wellesley Institute 2009, 1). Introduced in 2005, the city has an overall 30\% affordable housing policy for all residential construction over 200 units (Mah 2009, 36 and Wellesley Institute 2009, 1). However, because Quebec law does not permit mandatory inclusionary zoning, it is a voluntary policy (Mah 2009,36) and acts as a part of negotiations for density bonusing. The policy focuses on large projects, but does not exclude smaller ones (Mah 2009, 41). What is interesting is the fact that developments can, essentially, be compelled to provide affordable housing through referenda. In Sud-Ouest, local political will and active resident groups have been able to make the $30 \%$ policy a near requirement by petitioning against developments through opposing proposed by-laws that would be providing density bonuses (Mah 2009, 40). Development continues in the borough because developers are still making a profit (Mah 2009, 45). Another notable feature of this inclusionary policy is the split of the $30 \%$ requirement. $15 \%$ of this housing must be "social housing" while the remaining 15\% can be affordable rental or ownership units.

Montreal's strategy clearly has been successful in meeting its own goals. The number of units, and particularly their percentage of the total housing production on these sites, is impressive. (Wellesley Institute 2009, 8)

While the local context provides particularities that complicate comparison with other cities, and it is therefore important to note that Montreal has a history of much higher rentership and a large supply of rental housing (Klosteren 2012, 29). Like Vancouver, strong political will has also proven effective (Mah 2009, 46). Mayoral support has been crucial (Wellesley Institute 2009, 1). Likewise, an explicit commitment in the City of Montreal's 2004 Official Plan is that $30 \%$ of all new units be created affordable (Wellesley 
Institute 2009, 1), making policy implementation easier. Continuing, the success of the policy is largely dependent on borough governments, who, as part of negotiations for increased density, are able to use their "regulatory and planning tools to support affordable housing" which include "regulatory concessions, promoting or allowing lower-cost types of units, and using cost-saving standards or other measures" (Wellesley Institute 2009, 4) and could possibly offer expedited approvals, as one borough does (Wellesley Institute 2009, 4). In this way, it is interesting the way in which a voluntary requirement is enforced using incentive-based planning tools. As well, the split of the requirement (15\% social housing / $15 \%$ affordable housing) helps to address low-income household affordability issues, beyond what Vancouver's inclusionary policy has been able to target.

\section{San Francisco}

San Francisco provides another dimension to municipal policy seeking to encourage private sector participation in affordable housing construction. The city is facing tremendous upward real estate pressure, limited development potential and increasingly difficult access to secure affordable rental or ownership with average 2-bedroom rental rates approaching $\$ 4,500$ per month (Seifel 2014,6 ). As a result, the city has had to implement a number of policies and programs that attempt to provide affordable housing options for all of its residents. This has led to the introduction of an inclusionary zoning policy, a housing trust fund, an affordable housing trust fund, condominium conversion fees, development agreement affordable housing fees and establishing the Office of Community Investment and Infrastructure (OCII), which implements tax increment financing (TIFs) (Seifel 2014, 18).

First, San Francisco's inclusionary zoning policy applies to all residential developments over 10 units and requires developers to pay an Affordable Housing Fee or apply to construct affordable units on- or off-site in lieu of paying the fee (San Francisco Mayor's Office of Housing 2014). If units are constructed on-site, the requirement is between 12$15 \%$ of total units, depending on size and location of the development. However, if the units are provided off-site, the requirement increases to $20 \%$ (Seifel 2012, 2). In this way, the 
city lessens the requirement in order to encourage income mixing. Units can be rented or owned.

The city also introduced a housing trust fund in 2012 that, aside from a yearly general fund transfer of $\$ 20$ million, collects revenues from TIFs from the OCII, a portion of a Hotel Tax, general revenue increases due to increased business license fees as well as the newly introduced Proposition E (a tax reform measure) which will contribute 13 million dollars in its first year alone (Center for Community Change 2013). The fund will develop permanently affordable housing for households whose median income is $60 \%$ or below AGMI, implement incentives for onsite below market rate housing, invest in the City's down payment assistance program (who provide interest free loans for moderate income homebuyers) and create a program that helps distressed low and moderate income households remain in their homes (Center for Community Change 2013).

The Housing Office also administers the "Citywide Affordable Housing Fund" which collects a number of different fees including the Inclusionary Housing Fees described above, JobsHousing Linkage Fee, development agreement affordable housing fees, Condominium conversion fees as well as the Market-Octavia and Van Ness Fees, which are specific to particular areas (San Francisco Mayor's Office of Housing 2014, 18).

Again, an important lesson from San Francisco is the diversity of policies as well as the strength of their applications. Both the use of an inclusionary housing policy and a housing trust fund in conjunction with tax increment financing demonstrates two methods of extracting private capital as well as encouraging private sector participation. However, it is difficult to assess the success of both programs due to their recent introduction. However, it is projected that the Housing Trust Fund will be able to invest over $\$ 1.5$ billion over the next 30 years (Center for Community Change 2013). 


\section{U.S. Low Income Housing Tax Credit (LIHTC)}

It is also important to note a federal program in the United States that encourages private developers to develop affordable housing across the country. Since 1986, the United States has provided a sizable driver of private sector development of affordable housing, called the Low Income Housing Tax Credit (LIHTC) program, which allows developers to accumulate tax credits that can be sold to investors to lower development costs (Polton 2005,41 ). Developments, either new construction or rehabilitation, can qualify for the LIHTC program in two ways. First, developments must have at least $20 \%$ of units be occupied by households who have incomes below $50 \%$ of the "area median gross income" (AMGI) (Freedman \& Owens 2011, 117). Second, developments can qualify if $40 \%$ of units are occupied by households who have a combined income below $60 \%$ of the AMGI (Freedman \& Owens 2011, 117). In both cases, the development must cap annual rents for

the affordable units at $30 \%$ of the "income limit defined for the area" for at least 30 years. If these requirements are met, the project can access a 10-year stream of tax credits. However, the size of the credit is dependent on the percentage of units in the development that are affordable and as a result, $90 \%$ of units created under under the program qualify as affordable (Freedman \& Owens 2011, 117).

An interesting stipulation of the program is how the LIHTC encourages development to specific areas. If development occurs in Qualified Census Tracts (QCTs - low-income areas) or Difficult Development Areas (DDAs - areas with high construction, utility or land costs), the project is able to get $30 \%$ increase in credits (Freedman \& Owens 2011,117). The ways in which the QCTs have been identified, through the use of AMGI and metropolitan area definitions has evolved to include more areas since the programs introduction. This provides a noteworthy technique to encourage growth in particular areas in cities.

The program is administered on a state basis, with each state allocated a fixed amount of tax credit value. Between 1987 and 2007, the LIHTC program has subsidized over 31,000 developments, which include over 1.8 million units and accounts for over $5 \%$ of all renter occupied housing stock in the United States (Freedman \& Owens 2011, 116). Research has 
demonstrated that the LIHTC has been successful in creating affordable units in urban centres, however, it has largely directed development to low-income neighborhoods, which can be seen as a 'catch-22': a barrier for low-income residents' access to better jobs, schools and quality of life but conversely bringing development to particularly strained areas. (Freedman \& Owens 2011, 116). 


\section{PUBLIC AND PRIVATE SECTOR ASSESMENT}

Interviews were conducted to garner public and private sector opinions about the provision of affordable rental housing in Toronto. The interviews, which involved privatesector developers, not-for-profit housing providers and a member of the Affordable Housing Office at the City of Toronto provide a practical understanding of the particularities of development in Toronto and shed light on the potential tools that could be introduced and successfully implemented. Interviews, coupled with analysis of current municipal policies and plans, such as the City's Affordable Housing Action Plan, will assess the ability to implement potential strategies and tools.

\section{Private Sector}

During private, confidential meetings, private sector developers, as well as representatives of a not-for profit affordable housing provider expressed a number of important ideas and sentiments about affordable housing policy and construction in Toronto. All interview participants made mention of the impact that federal and provincial policy has had and continues to have on the city's ability to provide affordable housing and acknowledged the need for increased funding and prioritization from upper levels of government. "Housing is not a priority for any level of government" one interviewee stated. There was also a general sense from several participants about a strained relationship between the municipality and the private sector. Developers expressed a desire for transparent, accountable and flexible planning and development process. However, one participant, stating that the municipal government was "not holding their end of the bargain", expressed the feeling that the municipality was unable to deliver on their existing promises and scope of housing affairs. As a result, the participant struggled to believe that the municipal government would be able to effectively implement any new types of affordable housing policy solutions.

Developers agreed that housing issues need to be viewed as an economic process, considering all pieces of the puzzle as efficiencies or inefficiencies. That is to say, evaluating all parts of how buildings are constructed by categorizing each item as either lowering or raising the cost of construction. Some factors, such as regulation, that increase the cost, can be altered to provide more efficiency, thus a lower cost of construction and lower price to 
consumer. Similarly, developers stated that all additional costs, or inefficiencies, such as development charges, are passed on to the consumer (if the market allows). As a result, developers viewed increased regulation as making it more costly to build overall. This led to participants considering strong regulation requiring affordable housing construction as not being able to be introduced and implemented (pass council and appeals) in Toronto. As result, inclusionary zoning was not considered possible in Toronto. Not-for profit representatives, who agreed with inclusionary zoning in theory, did not think it was possible to implement in Toronto, echoed this sentiment. In the eyes of developers, increasing overall housing supply is the best way to address the high cost of housing in Toronto. One developer stated, "supply is the biggest thing for affordability", again, suggesting that with more requirements and costs levied on homebuilders, affordability will not be addressed.

Perceptions of the barriers to private sector affordable rental construction were largely tied to the inefficient development process (cost and time), absence of enough consistent, long term funding and the lack of municipal flexibility or ability to allow creative solutions. Definitions of "affordability" it was argued should be tied not only to monthly rent or cost of a home but also to the access to quality of life improvements. For example, the ability to live someplace that allows a household to not feel the need for a second vehicle or vehicle at all impacts overall affordability greatly. As well, affordability issues were challenged by the dynamics of Toronto's condominium market, given the added difficulty of understanding the rental market as not only being represented by purpose built rental units.

However, all participants agreed on the importance of affordable housing (rental and ownership), the increasingly problematic nature of provision in Toronto and the ability for the private sector to be suitably incentivized to participate. Tax incentives were attractive to developers, with one mentioning the success and structure of the American LIHTC program. As well, any way to decrease the inefficiency of the development process was well received. Fast tracked applications, reduced development charges, waiving other fees and 
other similar adjustments were regarded as helpful in closing the financial feasibility gap that exists for private developers and affordable housing construction.

Creativity was seen as a necessity when considering the development context of Toronto. Participants all mentioned the need for creative solutions, be it building affordable housing above an elementary school or flexible policy regarding the transfer of air rights. As well, developers expressed interest in a collaborative process with the municipality for finding solutions to affordable rental housing. Similarly, the importance of partnerships between developers and not-for profit providers, especially with purpose built rental, was articulated.

\section{Public}

The City of Toronto and the Affordable Housing Office (AHO) have identified the lack of affordable rental housing as a pressing issue. In 2008, the City of Toronto carried out public consultations in order to strengthen the 2007 Housing Opportunities Toronto Framework document. From that, the city was able to develop a 10-year affordable housing action plan entitled the "Housing Opportunities Toronto: An Affordable Housing Action Plan 20102020". The plan acknowledges both the importance of affordable rental housing as well as the particular need in Toronto. It seeks to be a "road map to steer the work and investment decisions of the City of Toronto in partnership with federal and provincial housing sectors over the next decade" (Affordable Housing Committee 2009, 6). Among eight strategic themes, the most important within the context of this research, is to "create new affordable rental homes". In this section, the city lays out the ways in which it will attempt to add more affordable units each year. The plan points to land costs as a major hindrance for affordable housing construction and points to the city's "Housing First" policy for publicly owned land. As well, the section points to the need for innovative and creative solutions to housing creation. This suggests that the city is prepared to consider new ideas for providing affordable housing on public land, such as building above schools. The document refers to the revitalization of TCHC sites, such as Regent Park or Lawrence Heights as well as the West Don Lands, suggesting that these types of partnerships, with affordable housing as a key feature, shall be pursued and welcomed. As well, the plan identifies the 
need to provide affordable housing that is "truly affordable" and beyond "just below market rents" (Affordable Housing Committee 2009, 33) recognizing the need of affordable housing to be built for low-income households, not just for moderate-income ones. Developers, as well, mentioned successful, ongoing participation with such revitalization projects. It seemed as though the developers were eager to participate in these types of affordable housing initiatives. However, it should be noted that few additional new affordable units are being created as part of ongoing revitalization, where the focus has been on replacing aging buildings (TCHC 2014).

Notable "City Actions" from the Action Plan that refer to the idea of involving private sector developers in the provision of affordable rental housing contribute to an understanding of the municipality's preparedness and openness to incentivizing or requiring affordable housing. Actions include allocating funds from development charges to affordable housing initiatives, reviewing the "Housing Incentives (Municipal Capital Facilities) Bylaw" (yet to be released) in order to extend further incentives to create affordable housing in mixed-use developments and condominiums and "encouraging the provision of affordable housing opportunities through the panning approvals process" (Affordable Housing Committee 2009,34 ), i.e. Section 37. As well, prioritization for affordable housing funding will be made to proposals that secure affordability of units for more than 20 years and proposals that include partner non-profit or non-profit cooperative housing providers (Affordable Housing Committee 2009, 34). From this, it can be surmised that private developers who can propose long-term affordable units, in conjunction with a non-profit housing provider have the potential to close the feasibility gap for private developments. However, the ability for these actions to be successful should be questioned. The lack of policy directly engaging the private sector may not be enough to convince private developers that constructing affordable housing is a good business decision. Similarly, actions explicitly directed at creating rental housing are absent.

The Affordable Housing Office attempts to use "what we have right now" to get affordable units constructed. Therefore, leveraging Section 37 negotiations as well as pursuing productive public-private partnerships is the AHO's primary way of engaging private sector 
developers in the construction of affordable housing. An employee at the AHO discussed the importance of upper-level government funding by describing how, when available and coupled with the City's "incentive package" (Development Charges waived, tax relief on affordable units, etc.), many private developers are interested in building affordable housing. However, without the upper-level government funding, projects are not feasible, as the incentives alone do not provide enough of a financial break. In addition, while the AHO acknowledged the power of inclusionary zoning, it was described as legislatively impossible in Ontario at the moment and their focus was therefore on using the current framework. However, notions of developers' feelings towards regulation (additional costs are passed down to consumer) were challenged by the AHO, as an interviewee stated that developers will "always build to the market...so introducing new regulations would mean developers would only change the way they value land and adjust accordingly". That is to say, the market would simply need to "catch-up" after the introduction of something like inclusionary zoning. According to the AHO, the City of Toronto has requested inclusionary powers from the Province that would allow such a policy to be introduced.

The Federation of Canadian Municipalities has proposed three initiatives for the federal government to address affordable housing in Canadian cities. They suggest a "Building Canada Rental Development Direct Lending Program" to stimulate investment in new market rental units, with the intention of increasing overall supply of rental units in an effort to bring down market rates. As well, the Federation recommends a "Rental Housing Protection Tax Credit" to preserve existing low-rent properties from demolition and condominium conversions and an "Eco-Energy Rental Housing Tax Credit" to improve quality, value and environmental impacts of such housing. Still lacking is the push for strong incentives for affordable rental housing.

The 2014 federal budget has "has failed to allocate a single new dollar for critical housing investments - despite the overwhelming national need and a growing chorus of experts pointing to the severe impact of the long-term erosion of existing federal housing investments." (Shapcott 2014b). There is a downward trend for federal housing funding. CMHC has reported that its primary national program will be reduced by almost half from 
$\$ 3.04$ billion in 2010 to $\$ 1.68$ billion in 2017. The same seven-year range will see 121,000 fewer households assisted by federal funding, as the number of supported households drops from 613,500 to 492,500 (Shapcott 2014b). Unfortunately, despite both the city's Action Plan and the Federation of Municipalities (among many) lobbying for federal support, it does not appear to be occurring. As a result, the focus must be placed upon municipality's capacity to leverage their resources to engage the private sector to contribute to the construction of affordable rental housing. 


\section{CONCLUSION \& RECOMMENDATIONS}

From a municipal perspective, there are a variety of actions that should continue to be pursued or begin to be undertaken. Beyond simply listing potential policies that the City of Toronto should implement, an understanding of the actions and process needed to achieve more affordable rental housing is necessary. How can the City of Toronto make affordable rental housing construction attractive to private sector developers? In Toronto, since many land use policy and agreements are struck by politicians, such a task can prove difficult. Section 37, for example is negotiated between a developer and the ward councillor. The importance of political will and mayoral support for housing issues cannot be understated. As a result, planners do not have the power, or final say, to always ensure that certain concerns (such as affordable rental housing) are being met. This does demonstrate the importance of planners' role as advisors and researchers. Similarly, there is a need, as articulated by the AHO, to develop policy that is strong both in its approach and implementation. A good policy is both well intentioned in its concept as well as its ability to deliver intended results. With these ideas in mind, the following provides actions and policies for the municipality of Toronto to consider pursuing to boost private sector developers in constructing affordable rental housing.

\section{Engage, Educate \& Consult}

An important component of this recommendation is engagement. Planners need to engage and educate local politicians with whom development negotiations and approvals flow through. Better understandings of issues, no doubt, result in stronger and more effective decisions (during Section 37 negotiations, for example). Enhanced communication between all levels of government would also improve the potential for coordinated strategies and mutual understanding around issues and needs. All interview participants identified the lack or inconsistency of upper-level government funding as a challenge to building affordable housing.

All interview participants also voiced a desire in developing and being part of creative and innovative solutions to address affordable housing shortages. In order for these types of ideas to be developed, inclusive consultations and discussion between all stakeholders are 
needed. Private sector developers also voiced an interest in participating in consultations with the municipality regarding affordable housing policy development. While this currently takes place, developers expressed a desire to have more meaningful inclusion in this process.

\section{Strengthen Partnerships}

As identified by reviewed literature and reports, case studies and interviews, public-private partnerships are essential for housing development. However, several interview participants expressed feelings counter to positive partnership development. Developers shared feelings of animosity, distrust or perceived laziness towards the municipal government as a whole. Similarly, public representatives dismissed developer claims about the act of passing on costs associated to increased regulation. However, for affordable housing to be built, strong, mutually beneficial partnerships need to be developed, maintained and modeled. As the above section prescribes, inclusive, transparent engagement and consultation can contribute to enhancing private-public partnerships.

It is essential to maximize the use of existing policies, tools and what upper-level government funding is available to encourage affordable housing development, and as a result, planners must seek to proactively establish relationships with developers, not-for profit housing providers and politicians. A positive local example of such partnerships would be the model being pursued by TCHC through the redevelopment of old public housing projects such as Regent Park and Lawrence Heights with a variety of developers such as The Daniels Corporation and Context Development. The Regent Park Revitalization, led by The Daniels Corporation, a private sector development firm, will not only be replacing existing rent-geared to income units located on publically owned land, but constructing at least 200 additional affordable housing either in or within close proximity to Regent Park, in addition to new market units (TCHC 2014). 


\section{Update Policy}

\section{Reassess Incentive Package}

As described by the AHO, the Toronto municipal government currently offers an incentive package that aims at reducing the soft costs of development (including waiving Development Charges). However, the incentives alone are unable to provide enough financial motivation for private sector developers to be interested in building affordable housing. Steps should be taken to increase the attractiveness of this incentive package. Financial breaks associated with the reduction of both the hard and soft costs of construction should be considered. Both the 'Rental 100' and Short Term Incentives for Rental Housing programs from Vancouver were able to successfully attract private sector developers to build affordable rental units. Likewise, the municipality of Toronto could elect to offer very attractive incentive package for a short period of time or to a certain maximum of developments in order to maintain a determined fiscal balance.

\section{Redesign Section 37}

Section 37 is a problematic tool for developing affordable housing. Mah (2009) suggests that Section 37 and the Large Sites policy "are not effective tools at generating affordable housing" (Mah 2009, 9), contending that up until 2009, only 18.9\% of Section 37 agreements involved affordable housing (Mah 2009, 9). The AHO referred to Section 37 as being a primary tool of involving private sector developers in the construction of affordable housing, however since many types of community contributions are also available as part of Section 37, affordable housing can be easily overlooked. The municipality must adjust the policy to properly account for this problem, whether it is through changing the negotiation process, by involving planners more directly or by adjusting the parameters of the policy to include affordable housing requirements.

\section{Secondary Plans \& The New Development Permit System (DPS)}

Secondary Plans have the potential to play a significant role in planning for affordable housing. Secondary Plans are created with community input to shape growth and stimulate investment or certain types of redevelopment in a given area (City of Toronto 2010, 5-9). As identified by a representative of the AHO, secondary plans present a promising way to 
implement local affordable housing requirements or incentives. Similarly, Community Improvement Plans can also be another way to implement affordable housing policies at a neighbourhood scale. Community Improvement Plans can leverage financial incentives such as loans, grants or tax assistance for site remediation, waiving development charges, development permit application fees or refunding the park dedication fee (City of Toronto 2010, 5-10). Both types of plans can also contribute to streamlining development applications.

The New Development Permit System (DPS) also presents another potential tool for implementing policies geared at encouraging affordable housing construction in certain areas. The DPS is proposing to create area-based plans that will "ensure that development is in keeping with the local needs expressed through the community's planned vision and objectives. The result will be a more comprehensive planning process in which outcomes are predictable and align with the expectations of the community" (City of Toronto 2014b, 1). The development of this new system should be closely followed and given consideration as a potential way for the municipality to implement further requirements or incentives for affordable housing.

\section{Introduce Policies}

While current policies exist that have the ability to be further utilized for encouraging private sector participation in constructing affordable housing, this research has demonstrated that with the introduction of new policies, the City of Toronto has the potential to implement policies that can contribute to building needed affordable housing. New policies could also deal with affordable housing directly and separately from other community contributions, as Section 37 does. Developing a suite of policies, by adding additional policies, would also contribute to creating a more resilient affordable housing investment system. Vancouver, Montreal and San Francisco all rely on a wider set of tools for creating new affordable housing, particularly rental housing. As well, many recommended policies and tools (both existing and recommended), require a strong development market since they only affect new construction (Section 37 or exaction fees, 
for example). If conditions change, there needs to be policies that continue to support the goal of providing affordable housing.

While a mandatory inclusionary zoning policy would not be legislatively possible at this time, several other tools are. The benefits of establishing a Trust Fund should be given serious consideration. While a strong, transparent administrative system would be essential, a trust fund would provide "greater certainty in financing and would allow housing developers to make long term housing plans" (Shapcott 2014a). Private sector developers have identified the current inability to provide long-term assurance of funding as a significant barrier to participating in the construction of affordable housing (Black 2012 , 21). As well, this fund would be able to solely finance affordable housing, as oppose to share funding between a set of municipal issues.

Both TIFs and Linkage Fees also provide further opportunities to engage private sector developers. TIFs have been used throughout the United States as a community-building tool. San Francisco has successfully implemented both tools in order to fund affordable housing exclusively. However, TIFs and Linkage Fees have yet to be implemented in Toronto and would require additional unfamiliar administrative processes. Regardless, the ability to leverage all types of new development that improve neighbourhoods (commercial development, for example) to contribute funding to affordable housing construction should be given consideration.

Lastly, the municipality should continue to lobby both provincial and federal governments for long-term commitments to funding affordable housing. Tax incentives were identified by private sector developers as compelling financial incentives to build affordable housing. However, tax incentives for rental construction through the CMHC's Multi Unit Rental Building program in the 1970 s were "condemned not only because it was an inefficient subsidy to private rental housing, but also because the government had little control over its fiscal cost" (Steele 2006, 31) and contributed to the shift from built private sector rental to condominiums. This would need to taken into consideration when designing tax incentives. 


\section{Final Considerations}

While all existing and recommended policies seek to encourage private sector construction of affordable housing, the municipality should commit to prioritizing affordable rental housing. As this research paper demonstrates, there is an increasing need for affordable rental housing in Toronto and the municipality has yet to implement sufficient policies that focus on this type of affordable housing. As mentioned above, no single policy should be viewed as a complete response to addressing housing shortages. Thibert (2007) points out that "if we accept the proposition that complex tasks require sophisticated solutions, then innovative planning and design schemes are more likely to be devised under flexible policy frameworks" (43) suggesting that municipal policies will need to be both flexible and sophisticated in order to effectively address an issue like affordable housing. A variety of policies would be most effective. In this way, short-term programs, as used in Vancouver, should be considered as not only a way to test policies (through pilot programs) but also as a way to jump-start private sector developers' interest in constructing affordable housing.

This research has made the argument for increasing private sector participation in affordable housing development in the City of Toronto. By exploring the need for affordable housing, the importance of providing affordable housing was understood. After examining the national, provincial and municipal legislative situation affecting Toronto, an understanding of the federal and provincial government retrenchment from social housing funding demonstrated a need for municipalities to implement new policies and leverage planning tools to produce more affordable housing. As well, an explanation of Toronto specific policies provided an understanding of existing legislative context in the city. A description of Toronto's rental housing situation and development context highlighted the place-specific challenges of affordable rental construction. Next, a curated assortment of policies used across Canada and the United States to encourage or require affordable housing contributions from private sector developers were explored. Case studies of Vancouver, Montreal and San Francisco highlighted how municipalities facing similar housing pressures have attempted to address their situations. Interviews with key actors have contributed Toronto-specific ideas and opinions about private sector involvement in 
the construction of affordable rental housing as well as the accompanying policies that would or would not be considered applicable to Toronto. Finally, actions and policies have been recommended for the consideration of the Toronto municipal government. Toronto is in need of new affordable housing and this research has explored important policies and tools that can be used to boost overall affordable rental housing through private sector participation. 


\section{WORKS CITED}

\section{Authored Citations}

Amborski, D. (2013). Municipal Finance. School of Urban and Regional Planning. Fall Semester, Ryerson University.

Burda, C. (2013). Priced Out: Understanding the factors affecting home prices in the GTA. Royal Bank of Canada \& Pembina Institute. Retrieved between January $1^{\text {st }}$ - April $1^{\text {st }}$, 2014 at: http://www.rbc.com/newsroom/pdf/Priced-Out-1202-2013.pdf

Carter, T. (2013). Housing Issues, Challenges and Solutions in Rural Communities. Carter Research Associates, Inc. Presentation to Portage la Prairie and Central Plains Housing Forum. March 13 ${ }^{\text {th }}, 2013$, Portage la Prairie, Manitoba.

Falvo, N. (2007). Addressing Canada's Lack of Affordable Housing. Canada Economics Association. 1-40.

Fischel, W. A. (2005). The Homevoter Hypothesis: How Home Values Influence Local Government Taxation, School Finance, and Land-Use Policies. (Boston, Massachusetts): Harvard University Press.

Freedman, M., Owens, E., G. (2011). Low-income housing development and crime. Journal of Urban Economics. Vol. 70: 115-131.

Gillespie, K. (2001). Toronto tenants get less but pay more Sky-high tax rates are fuelling the equality debate. The Toronto Star. Published October 21, 2001. Retrieved between January $1^{\text {st }}$ - April $1^{\text {st }}, 2014$ at:

http://www.ontariotenants.ca/taxes/articles/2001/ts-01j21.phtml

Hulchanski, J.D. (2002). Housing Policy for Tomorrow's Cities. Canadian Policy Research Networks. Ottawa, Ontario. 1 - 40.

Hulchanski, D. (2003) "What Factors Shape Canadian Housing Policy? The Intergovernmental Role in Canada's Housing System" Conference on Municipal-Federal-Provincial Relations in Canada. 1 - 30.

Kolsteren, A. (2012). Affordable Housing In Toronto: Legislative And Regulatory Tools For Municipal LED Development. Ryerson University Theses and Dissertations. Paper 1547.

Krueckeberg, D. A. (1999) "The Grapes of Rent: A History of Renting in a Country of Owners." Housing Policy Debate Vol. 10, No. 1: 9-30.

Laird, G. (2007). Shelter: Homelessness in a growth economy: Canada's 21st century paradox. Sheldon Chumir Foundation for Ethics in Leadership. Calgary, Alberta. 
Retrieved between January $1^{\text {st }}-$ April 1st, 2014:

http://www.chumirethicsfoundation.ca/files/pdf/SHELTER.pdf

Landau, J. (2014). Ontario Moves Forward with Six-Storey Wood-Frame Construction. Urban Toronto. Retrieved April 8th 2014 at:

http://urbantoronto.ca/news/2014/03/ontario-moves-forward-six-storey-woodframe-construction

Lewchuk, S. (2013). Affordable housing in Canada: an economically sound investment. Citizens for Public Justice. Retrieved between January $1^{\text {st }}-$ April $1^{\text {st }}, 2014$ at: http://www.cpj.ca/content/affordable-housing-canada-economically-soundinvestment

Mah, J. (2009). Can Inclusionary Zoning Help Address the Shortage of Affordable Housing in Toronto? Canadian Policy Research Networks. Ottawa, Ontario. 1-51.

Moosebraaten, L. (2013). East Bayfront condo may incorporate affordable rental units purchased by City of Toronto. The Toronto Star. Published October 29, 2013.

Retrieved between January $1^{\text {st }}-$ April $1^{\text {st }}, 2014$ at:

http://www.thestar.com/news/gta/2013/10/29/east_bayfront_condo_may_incorpor ate_affordable_rental_units_purchased_by_city_of_toronto.html

Morrow, A. \& Church, E. (2013). Social Housing at Risk as Ontario, Toronto spar. The Globe and Mail. Published June 24, 2013. Retrieved between January $1^{\text {st }}-$ April $1^{\text {st }}, 2014$ : http://www.theglobeandmail.com/news/toronto/ford-says-ontario-rejects-plea-topreserve-funding-to-pay-for-social-services/article12785099/

Oleson, D. (2013). Should Toronto Build Affordable Housing Above Public Facilities?. The Toronto Star. Published March 18, 2014. Retrieved March 20th 2014 at: http://livenews.thestar.com/Event/Star_Big_Ideas_Should_Toronto_build_affordable_ housing_over_public_facilities?Page $=0$

Polton, R. E. (2005). Fundamentals of the Low Income Housing Tax Credit Program. The Appraisal Journal. Vol. 73, No. 1: 39-46.

Porter, D.R. (2004). The Promise and Practice of Inclusionary Zoning. In A. Down (ed.) Growth Management and Affordable housing: Do they Conflict?. Washington, DC: The Brokkings Institution, pp. 212-263.

Scherlowski, D. (1999). Municipal Regulatory Initiatives: Providing for Affordable Housing. Richard Drdla Associates Inc.

Seifel, L. (2012). Inclusionary Housing Analysis. Report for San Francisco Mayor's Office of Housing. Retrieved between January $1^{\text {st }}-$ April 1 1st, 2014: http://sfmoh.org/modules/showdocument.aspx?documentid=6976 
Seifel, L. (2014). San Francisco’s Affordable Housing Affordability Gap. Seifel Consultants. Presentation for San Francisco Mayor's Office of Housing. Retrieved between January $1^{\text {st }}$ - April 1st $2014:$ http://www.sfmoh.org/modules/showdocument.aspx?documentid=7734

Shapcott, M. (2014a). What's My Big Idea? An Affordable Housing Trust Fund For Toronto. Wellesley Institute. Retrieved between January $1^{\text {st }}-$ April $1^{\text {st }}, 2014$ at: http://www.wellesleyinstitute.com/housing/whats-my-big-idea-an-affordablehousing-trust-fund-for-toronto/

Shapcott, M. (2014b). Federal Budget Fails to Deliver Investments to Meet National Needs. Wellesley Institute. Retrieved between January $1^{\text {st }}-$ April $1^{\text {st }}, 2014$ at: http://www.wellesleyinstitute.com/housing/federal-budget-2014-fails-to-deliverhousing-investments-to-meet-national-needs/

Simpson, J. (2011). Strike a blow for democracy: Scrap the OMB. The Globe and Mail. Published January 28, 2011. Retrieved between January $1^{\text {st }}-$ April $1^{\text {st }}, 2014$ : http://www.theglobeandmail.com/globe-debate/strike-a-blow-for-democracy-scrapthe-omb/article621920/

Steel, M. (2006). A Tax-Based Affordable Housing Program for Canada. Canadian Housing. $31-38$.

Thibert, J. (2007). Inclusion and Social Housing Practice in Canadian Cities: Following the Path from Good Intentions to Sustainable Projects. Canadian Policy Research Networks. Ottawa, Ontario. 1- 60.

\section{Organization-based Citations}

Affordable Housing Committee (2009). Housing Opportunities Toronto An Affordable Housing Action Plan 2010-2020. City of Toronto. Retrieved between January $1^{\text {st }}-$ April 1' st 2014: http://www.toronto.ca/affordablehousing/pdf/hot_actionplan.pdf

Altus Group. (2013). Government Charges and Fees on New Homes in The Greater Toronto Area. BILD Toronto. Retrieved between January $1^{\text {st }}-$ April $1^{\text {st }}, 2014$ : http://www.bildgta.ca/BILD/uploadedFiles/Government_Relations/2013/REVISED \%20Government\%20Charges\%20in\%20the\%20GTA\%20-\%20July\%2023.pdf

Center for Community Change. (2013). San Francisco Announces First Investment from New Housing Trust Fund. Retrieved between January $1^{\text {st }}-$ April $1^{\text {st }}, 2014$ : http://housingtrustfundproject.org/san-francisco-announces-first-investment-fromnew-housing-trust-fund/

City of Toronto. (2010). Toronto Official Plan. (Toronto, ON). 
City of Toronto. (2013) "Affordable Housing." Retrieved on January 14th 2014 . Retrieved between January $1^{\text {st }}-$ April 1 $1^{\text {st }}, 2014$ :

http://www1.toronto.ca/wps/portal/contentonly?vgnextoid=b06d0f1025c21410VgnVC M10000071d60f89RCRD\&vgnextchannel=9632acb640c21410VgnVCM10000071d60f89 $R C R D$

City of Toronto. (2014a). Residential Development Chargers Rates, Effective February 1, 2014. Corporate Finance Division. Retrieved between January $1^{\text {st }}-$ April $1^{\text {st }}, 2014$ : https://www1.toronto.ca/City\%200f\%20Toronto/Corporate\%20Finance/Developm ental\%20Charges/Files/pdf/D/DC\%20Rates\%20Effective\%20February\%201,\%2020 14_1.pdf

City of Toronto. (2014b). ResetT0: Towards Neighbourhood Planning. Department of Planning. Retrieved April 3rd 2014:

http://www1.toronto.ca/City\%200f\%20Toronto/City\%20Planning/Zoning\%20\&\%2 0Environment/Files/pdf/R/Reset_TO_Toolkit_2014.pdf

City of Vancouver. (2010). Short Term Incentives for Rental (STIF) Frequently Asked Questions. Retrieved between January $1^{\text {st }}-$ April $1^{\text {st }} 2014$ : http://vancouver.ca/files/cov/stir-faq.pdf

City of Vancouver. (2012a). Results of Short Term Incentives for Rental (STIR) Program. Presentation to Vancouver City Council. Vancouver Planning and Development Services. March $27^{\text {th }}, 2012$. Retrieved between January $1^{\text {st }}-$ April $1^{\text {st }}, 2014$ : http://vancouver.ca/files/cov/stir-presentation.pdf

City of Vancouver. (2012b). Secured Rental Market Housing Policy. Retrieved between January $1^{\text {st }}-$ April $1^{\text {st }} 2014$ : http://vancouver.ca/files/cov/secure_market_rental_policy.pdf

City of Vancouver. (2013). Process for Implementing Interim Rezoning Policy on Increasing Affordable Housing Choices Across Vancouver's Neighborhood. Vancouver Planning and Development Services. Retrieved between January $1^{\text {st }}-$ April $1^{\text {st }}, 2014$ : http://former.vancouver.ca/commsvcs/bylaws/bulletin/i002.pdf

City of Vancouver. (2014). Creating New Market Rental Housing. Retrieved between January $1^{\text {st }}$ - April 1 1st, 2014: http://vancouver.ca/people-programs/creating-newmarket-rental-housing.aspx

CMHC (Canadian Mortgage and Housing Corporation). (2006). Rental Market Report: Toronto CMA. Retrieved between January $1^{\text {st }}$ - April 1 15t, 2014 at: http://www.urbancentre.utoronto.ca/pdfs/gtuo/2006_Toronto_CMA_Rental_Market. pdf

CMHC (Canadian Mortgage and Housing Corporation). (2013a). Ontario Rental Market Report. CMCH. Retrieved between January $1^{\text {st }}-$ April $1^{\text {st }}, 2014$ at: 
http://www.cmhc-schl.gc.ca/odpub/esub/64507/64507_2013_B02.pdf

CMHC (Canadian Mortgage and Housing Corporation). (2013b). Rental Market Report: Greater Toronto Area. Retrieved between January $1^{\text {st }}$ - April 1 ${ }^{\text {st }}, 2014$ at: http://www.cmhcschl.gc.ca/odpub/esub/64459/64459_2013_A01.pdf?fr=1395259278824

CMHC (Canadian Mortgage and Housing Corporation). (2013c). Housing Market Outlook: Canada Edition. Retrieved between January 1 ${ }^{\text {st }}$ - April 1st, 2014 at: http://www.cmhcschl.gc.ca/odpub/esub/61500/61500_2013_Q01.pdf

CMHC (Canadian Mortgage and Housing Corporation). (2013d). Ontario Rental Market Report. CMCH. Retrieved between January $1^{\text {st }}-$ April $1^{\text {st }}, 2014$ at: http://www.cmhc-schl.gc.ca/odpub/esub/64507/64507_2013_B02.pdf

Department of Finance. (2010). Canada's Economic Action Plan: Year 2, Sixth Report. Government of Canada. Retrieved between January $1^{\text {st }}$ - April 1st, 2014: http://www.fin.gc.ca/pub/report-rapport/2010-09-27/pdf/ceap-paec-2010-09eng.pdf

FCM (Federation of Canadian Municipalities). (2012). The Housing Market and Canada's Economic Recovery. Retrieved between January $1^{\text {st }}$ - April 1st, 2014: http://www.fcm.ca/Documents/reports/The_Housing_Market_and_Canadas_Economi c_Recovery_EN.pdf

FCM (Federation of Canadian Municipalities). (2014). Mayors say cities held back by housing costs and transportation gridlock. Press Release. Retrieved between January $1^{\text {st }}$ - April 1st 2014 : http://www.fcm.ca/home/media/news-releases/2014/mayorssay-cities-held-back-by-housing-costs-and-transportation-gridlock.htm

Housing Connections. (2007). 2007 Annual Report. Retrieved between January $1^{\text {st }}$ - April $1^{\text {st }}, 2014$ : http://www.housingconnections.ca/pdf/annualReports/2007/Annual\%20Report\%2 02007.pdf

Housing Connections. (2013). 2013 Annual Report. Retrieved between January $1^{\text {st }}$ - April $1^{\text {st }}, 2014$ :

http://www.housingconnections.ca/pdf/annualReports/2013/2013\%20Annual\%20 Report.pdf

Housing Connections. (2014). Monthly Statistical Report. Retrieved between January $1^{\text {st }}$ April 1st, 2014:

http://www.housingconnections.ca/pdf/MonthlyReports/2014/Monthly\%20Report \%20-\%20Jan\%202014.pdf 
Mayor's Homelessness Taskforce Report. (1999). Taking Responsibility for Homelessness: An Action Plan for Toronto. City of Toronto. Toronto, Ontario.

Ministry of Infrastructure. (2006). Places to Grow: Growth Plan for the Greater Golden Horseshoe (Toronto, ON): Queen's Printer for Ontario.

Ministry of Finance. (2009). 2006 Census Highlights: Factsheet 12. Government of Ontario. Retrieved between January $1^{\text {st }}-$ April $1^{\text {st }}, 2014$ at: http://www.fin.gov.on.ca/en/economy/demographics/census/cenhi06-12.html

Ministry of Municipal Affairs and Housing. (2011). Municipal Tools for Affordable Housing. Provincial Planning Policy Branch. (Toronto, Ontario). 1-25.

Ministry of Municipal Affairs and Housing. (2012). Municipal Financial Incentives for Brownfield Redevelopment. Retrieved between January $1^{\text {st }}-$ April $1^{\text {st }}, 2014$ at: http://www.mah.gov.on.ca/Page9816.aspx

Ministry of Municipal Affairs and Housing. (2014). Provincial Policy Statement. (Toronto, ON): Publications Ontario Bookstore.

National Association of Realtors. (2012). Social Benefits of Homeownership and Stable Housing. National Association of Realtors Research Division. Available at : http://www.realtor.org/sites/default/files/social-benefits-of-stable-housing-201204.pdf

Options for Homes. (2014) The Options Contribution to your Down Payment. Retrieved between January $1^{\text {st }}-$ April 1st, 2014 at: http://www.optionsforhomes.ca

San Francisco Mayor's Office of Housing. (2014). Mayor's Office of Housing and Community Development. Retrieved between January $1^{\text {st }}-$ April $1^{\text {st }}, 2014: \underline{\text { http://www.sf- }}$ moh.org/index.aspx?page $=321$

Statistics Canada. (2011). Homeownership and Shelter Costs in Canada. Government of Canada. Retrieved between January $1^{\text {st }}-$ April $1^{\text {st }}, 2014$ at: http://www12.statcan.gc.ca/nhs-enm/2011/as-sa/99-014-x/99-014-x2011002eng.cfm\#a2

TCHC. (2013). About Us. Toronto Community Housing Corporation. Retrieved between January $1^{\text {st }}-$ April 1st, 2014: http://www.torontohousing.ca/about

TCHC. (2014). Expanding Housing Options. Toronto Community Housing Corporation. Retrieved between January $1^{\text {st }}$ - April 1'st, 2014: http://www.torontohousing.ca/about

University of Florida Law. (2014). Exactions \& Impact Fees. Retrieved between January $1^{\text {st }}$ - April 1't, 2014: https://www.law.ufl.edu/_pdf/academics/centersclinics/clinics/conservation/resources/exactions.pdf 
Urbanation. (2014). Record Year for Toronto Condo Rentals. Retrieved between January $1^{\text {st }}$ - April 1 1st, 2014 at: http://www.urbanation.ca/news/45-record-year-toronto-condorentals

Wellesley Institute (2005). The Blue Print to End Homelessness in Toronto: A Two-part Action Plan. Retrieved between January $1^{\text {st }}-$ April $1^{\text {st }}, 2014$ : http://www.wellesleyinstitute.com/wpcontent/uploads/2011/11/TheBlueprintfinal.pdf

Wellesley Institute. (2009). Montreal, QB: Inclusionary Zoning Policy. Retrieved between January $1^{\text {st }}$ - April $1^{\text {st }}, 2014$ : http://www.wellesleyinstitute.com/wpcontent/uploads/2010/03/CaseStudyMontreal.pdf

Wellesley Institute. (2010). Chicago Case Study (Inclusionary Zoning). Retrieved between January $1^{\text {st }}$ - April $1^{\text {st }}, 2014$ at: http://www.wellesleyinstitute.com/wpcontent/uploads/2010/03/CaseStudyChicago.pdf 